RISE OF BANK COMPETITION:

EVIDENCE FROM BANKING DEREGULATION IN CHINA

Haoyu Gao

Hong $\mathrm{Ru}$

Robert Townsend

Xiaoguang Yang

WORKING PAPER 25795 
NBER WORKING PAPER SERIES

\title{
RISE OF BANK COMPETITION: EVIDENCE FROM BANKING DEREGULATION IN CHINA
}

\author{
Haoyu Gao \\ Hong $\mathrm{Ru}$ \\ Robert Townsend \\ Xiaoguang Yang \\ Working Paper 25795 \\ http://www.nber.org/papers/w25795
NATIONAL BUREAU OF ECONOMIC RESEARCH
1050 Massachusetts Avenue
Cambridge, MA 02134
May 2019

We thank Emily Breza, Vedran Capkun, Hui Chen, Hans Degryse, Yongheng Deng, Daniel Ferreira, Rainer Haselmann, Zhiguo He, Christoph Herpfer, Haizhou Huang, Jennifer Huang, Sheng Huang, Yi Huang, Divya Kirti, Chen Lin, Shu Lin, Paul Malatesta, Alberto Manconi, Jun Qian, Wenlan Qian, Yingyi Qian, Zheng Song, Jian Wang, Pengfei Wang, Shang-Jin Wei, Wei Xiong, Hong Yan, Bernard Yeung, and Tianyu Zhang. We also thank conference discussants and participants of ABFER 2018; AFA 2018; CFRC 2017; CICF 2017; CIFFP 2018; EFA 2018; NBER 2017; SFS Cavalcade Asia-Pacific 2017; the NTU Finance Conference; the Geneva International Macroeconomics and Finance Workshop; the JLFA of the London Business School; the 12th Conference on Asia-Pacific Financial Markets (best paper award); the 30th AsianFA Annual Meeting; the 2nd New Institutional Accounting Conference (best paper award); an CKGSB, HKIMR, NUS, RMU, PBCSF, and UIBE seminars. We acknowledge in-kind support received for China Banking Regulatory Commission data access. Hong $\mathrm{Ru}$ gratefully acknowledges financial support from Ministry of Education, Singapore, under its Tier 1 RG60/17 and financial support from Hong Kong Institute for Monetary and Financial Research. This paper represents the views of the authors, which are not necessarily the views of the Hong Kong Monetary Authority, Hong Kong Institute for Monetary and Financial Research, or its Board of Directors or Council of Advisers. The above-mentioned entities except the authors take no responsibility for any inaccuracies or omissions contained in the paper. The views expressed herein are those of the authors and do not necessarily reflect the views of the National Bureau of Economic Research.

NBER working papers are circulated for discussion and comment purposes. They have not been peer-reviewed or been subject to the review by the NBER Board of Directors that accompanies official NBER publications.

(C) 2019 by Haoyu Gao, Hong Ru, Robert Townsend, and Xiaoguang Yang. All rights reserved. Short sections of text, not to exceed two paragraphs, may be quoted without explicit permission provided that full credit, including (C) notice, is given to the source. 
Rise of Bank Competition: Evidence from Banking Deregulation in China Haoyu Gao, Hong Ru, Robert Townsend, and Xiaoguang Yang

NBER Working Paper No. 25795

May 2019

JEL No. G21,G28,L50,O40

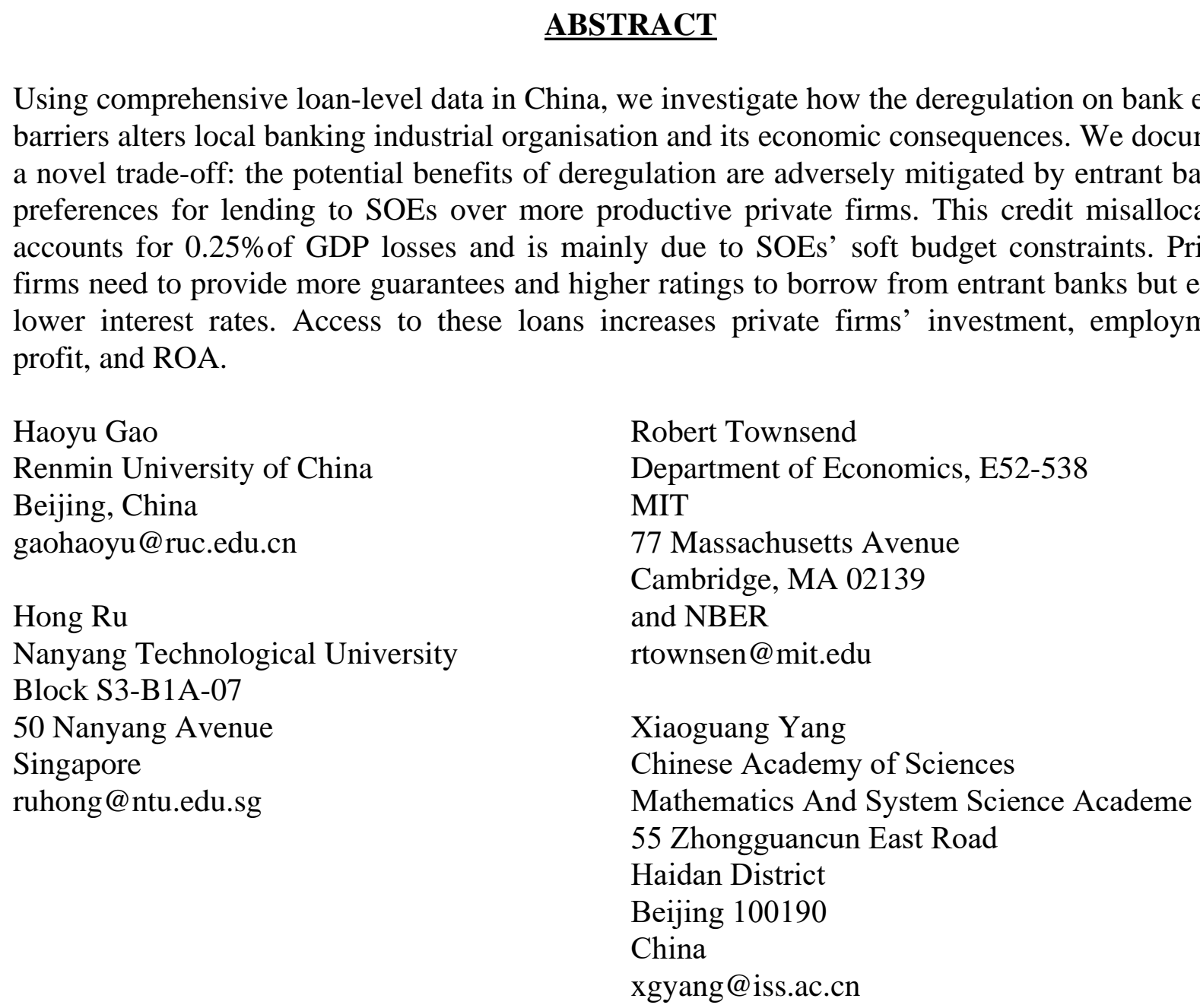




\section{Introduction}

Banks are the most important financial intermediaries in many countries and play an essential role in economic growth, while banking sectors are often heavily regulated (e.g., Barth, Caprio and Levine (2013)). A closely related central question in the debate concerns whether bank deregulation and increased competition are desirable or not. The literature has shown opposing views and mixed evidence. For example, increased bank competition may be beneficial to borrowers by lowering borrowing costs (e.g., J ayaratne and Strahan (1996)) but can also have negative consequences such as risk taking (e.g., Keeley (1990); Allen and Gale (2000); Jiang, Levine and Lin (2017)). ${ }^{1}$

This paper uses individual loan-level data to separate the costs and benefits of increased bank competition in China, the largest bank loan market in the world. ${ }^{2}$ We find that following deregulation in the form of geographically lowered bank entry barriers, banks entering into deregulated cities significantly increased lending amounts, as anticipated. However, the impact was filtered through and altered the local industrial of banks, and the potential benefits were adversely mitigated by a preference for lending to state-owned enterprises (SOEs) over more productive private firms. In particular, the soft budget constraints of SOEs, with implicit government guarantees, make new entrant banks prefer inefficient SOEs to contemporaneously opaque local private firms. For private firms that did receive bank loans, the entrant banks required more guarantees and higher internal loan ratings as indicators of quality. In the longer run, entrant banks learned the characteristics of local private firms and lent more to them, but a sizeable amount of money lent to SOEs in new markets was "lost" (approximately $0.25 \%$ of annual GDP). In addition to this loss, there were immediate beneficial impacts. The on-lending interest

\footnotetext{
1 In addition, J iang, Levin and Lin (2019) find that the bank entry deregulation leads to decreased liquidity creation that is a key banking function and helps accelerate economic growth. For a more detailed discussion on the costs and benefits of increased bank competition, see the survey papers by Berger et al. (2004) and Allen et al. (2001). In particular, see Allen, Qian and Qian (2008) for a survey of China's financial system, especially on banking regulation.

2 The total value of bank loans made in China reached USD19.6 trillion in Feb 2018, ranking first across the globe. The US ranks second, with USD9.1 trillion (https:// www.ceicdata.com/ en).
} 
rates in deregulated cities decreased significantly following deregulation, and the private firms that received such credit achieve yet higher levels of grouth and profitability. We describe this phenomenon as a novel trade-off of banking deregulation and in turn contribute to the ongoing debate.

More specifically, we study the impacts of the 2009 partial bank entry deregulation on bank competition dynamics and consequent economic activities. Regarding the industrial organisation setting in 2008, the big five state-owned commercial banks dominated China's banking system with 51,557 branches covering $85 \%$ of the country, while twelve joint equity banks, suppressed severely in regard to competition, had only 4,161 branches covering $9 \%$ of the country. ${ }^{3}$ Moreover, the China Banking Regulatory Commission (CBRC) restricted joint equity bank expansion by allowing such banks to apply for only one branch in any one city. In April 2009, the CBRCpartially lifted this entry barrier and allowed joint equity banks to open branches freely in a city in which they had already established branches. Additionally, joint equity banks were allowed to freely enter all cities in a province if they had operated branches in that province's capital city. Overall, $38.5 \%$ of joint equity bank-city pairs were deregulated, while others were still subjected to entry barrier regulation. ${ }^{4}$

The 2009 deregulation policy offers a difference-in-differences (DID) empirical setting. In particular, big five banks in cities in which no joint equity banks have been allowed to expand can be thought of as mostly immune to the deregulation shock and serve as the control group. This approach allows us to study various treatment effects on how entrant joint equity banks compete, how the incumbent big five banks respond, and how firms react in deregulated cities relative to regulated cities (i.e., control group). The exogenous variation in deregulation is at the bank-city-

\footnotetext{
3 We can broadly categorise banks in China into three groups: big five commercial banks at the top of the hierarchy, twelve joint equity banks in the middle of the hierarchy, and 131 local municipal banks at the bottom of the hierarchy. See Section 2.1 for a more detailed discussion.

4 Note that under preexisting regulation, some joint equity banks had branches in cities that, for other equity banks became deregulated. Relatedly, a traditional Herfindahl-Hirschman index might not capture the real competition dynamics as in many other situations (e.g., Claessens and Laeven (2004)).
} 
time level since the 2009 policy only deregulates specific regions and banks, depending on banks' branch distributions before deregulation. We take great care not to confound this deregulation with common economic time trends at the national level. ${ }^{5}$ In addition, bank lending and firm activities move in parallel between deregulated and regulated cities before deregulation, which supports the key assumption of the DID method.

Our primary data are collected from the registry system of banking regulator, which records detailed loan-level information on the 17 largest commercial banks in China from 2006 to 2013. The loan-level data cover all borrowers with an annual credit line of over RMB50 million (approximately US $\$ 8$ million), which represents approximately 80\% of the total bank loan market in China. Moreover, for each loan, the data record specific contract terms such as borrower and lender IDs, loan sizes, and maturity levels, and we can also trace internal rating changes and delinquent events at the monthly level. We match the loan data to Chinese Industry Census (CIC) firm-level data by the firm ID. This allows us to trace each loan a firm borrowed and to study how firms react to deregulation in terms of their investment, employment, performance, and profitability trends.

First, we document howjoint equity banks expand and compete with the big five banks. J oint equity banks have been growing substantially since the 2009 deregulation. For example, their market share increased from $24.5 \%$ in 2008 to $33.5 \%$ in 2010 . The percentage of cities covered by joint equity banks significantly increased from 9.5\% in 2008 to 15.7\% (by 65.3\%) in 2010, while the big five banks barely increased their coverages (by only $2 \%$ ) over the same period. Consistent with these unconditional patterns, the DID regressions show that the lending amount of joint equity banks increased by $31.2 \%$ in deregulated cities relative to banks in regulated cities, while lending amounts from the big five banks barely changed. On the other hand, the 2009 deregulation had insignificant effects on deposits. This is due mainly to a strict deposit interest

\footnotetext{
5 For example, the Chinese government initiated the RMB 4 trillion stimulus program in November 2008. We find that the growth rates of loans outstanding before the RMB 4 trillion program (i.e., Nov 2008) and before deregulation (i.e., April 2009) are similar across the control and treatment groups.
} 
rate cap, so joint equity banks must offer the same interest rate to depositors as the big five banks. Competition is not at the level of deposit mobilization.

Second, we study where the increased credit from entrant banks flowed to. Surprisingly, following deregulation, joint equity banks made more loans to SOEs in deregulated cities. SOEs in China, similar to those in many other countries, are much less efficient than private firms and distort credit allocation. ${ }^{6}$ In particular, the DID regressions show that within one year after deregulation, joint equity banks' SOE loans outstanding and shares of SOE loans made in deregulated cities increased by $39.3 \%$ and $18.6 \%$, respectively. This pattern weakens in the twoyear window following deregulation (i.e., 33.5\% and 15.8\% increases in SOE loan amounts and shares, respectively) and becomes insignificant in the three-year window. This finding suggests that although the distortion is massive, it is short-term (i.e., within two years). In addition, the incumbent big five banks in deregulated cities did not significantly alter their lending to SOEs following deregulation. Overall, more credit flows to SOEs in terms of level and share in deregulated cities.

This distortion of SOEs requires elaboration, and we gain additional insights from two analyses. On the one hand, it is well documented that SOEs enjoy softer budget constraints due to social stability concerns, policy burdens, and explicit or implicit government guarantees (e.g., Qian and Roland (1998); Lin and Tan (1999); Cull and Xu (2003, 2005); Ai et al. (2016)). We find that among SOEs, joint equity banks in deregulated cities lent significantly more to less efficient SOEs (i.e., lower TFP) in the two-year window, which further distorted credit allocation. These less efficient SOEs have greater assets on average and rank higher in the political hierarchy, which equips them with softer budget constraints (i.e., stronger implicit government guarantees).

${ }^{6}$ In China, SOEs have been criticised for inefficiency, and banks (many of them are state-owned) prefer to lend to SOEs, which has resulted in a large volume of nonperforming loans and increased risks in financial and economic systems (e.g., Allen, Qian and Qian (2005); Hsieh and Klenow (2009); Allen and Qian (2014); Hsieh and Song (2015); Song and Wu (2015); Song and Xiong (2018); Cong et al. (2019)). Politicians in China can also distort resource allocation. For example, Huang, Pagano and Panizza (2017) document that local government debts in China crowd out more productive private firms. 
On the other hand, new entrant joint equity banks typically lack sufficient information on local borrowers (e.g., Dell'Ariccia and Marquez (2004)) and tend to reduce credit risks in the short run by lending to SOEs with soft budget constraints. We use novel data that record the monthly internal ratings of individual loans to directly measure banks' information on borrowers, i.e., banks predict loan delinquency and downgrade the ratings before late payments. We find that banks can predict approximately $22.6 \%$ of the delinquency events within two years after a branch opening, while this ratio increases to $42.3 \%$ after the third year, suggesting that new entrant banks indeed cannot completely overcome the disadvantage of having inferior information about local borrowers at the beginning but can accumulate more information over time. In short, the soft budget constraints of SOEs generated an information threshold, below which SOE lending dominated lending to contemporaneously opaque local private firms. When these entrant banks accumulate more information on local firms, they start to increase lending to more productive firms in the long run, as we find in the data.

Next, we try to understand how deregulation affects loan contract terms and loan performance. In particular, for private firm loans from new entrant joint equity banks, DID regressions show that the deregulation led to $0.8 \%$ and $8.7 \%$ increases in the internal loan ratings and third party guarantees, respectively. Consequently, with such higher screening standards, deregulation led to a $62.5 \%$ relative decrease in the default rates for private firms. These higher lending standards and improved loan performance are not significantly observed for SOE loans. In short, these findings consistently support our hypothesis behind the worsening credit allocation: for private firms, the new entrant joint equity banks require higher internal loan ratings and more third-party guarantees to mitigate the information disadvantage, and credit risks are reduced consequently. These requirements are not necessary for SOEs due to their soft budget constraints.

In addition to the stringent lending standards for private firms that would help joint equity banks tease out private firms that have credit constraints but are of good quality, we find that 
the 2009 deregulation also led to a $6.6 \%$ decrease in the interest rates of private firms but had no significant effects on SOEs' borrowing costs. Consequently, private firms benefit significantly more from deregulation than SOEs can in terms of growth and profitability. In particular, we restrict our sample to firms that have borrowed from banks, as such firms should be affected directly by loan contract term changes caused by deregulation. DID regressions show that the 2009 deregulation led to increases in the growth rates of fixed assets and in the number of employees for private firms by $33.6 \%$ and $11.2 \%$, respectively. In addition to stronger growth in size, deregulation also led to increases in private firms' net income growth and ROA by $91.8 \%$ and $21.6 \%$, respectively. In contrast, SOEs do not benefit in deregulated cities. This suggests that credit not granted to more productive private firms was not used productively and was in some sense "lost", emphasising the potential unintended adverse consequences of banking deregulation in China.

Moreover, we control for year and firm fixed effects, and the pretrend dummies have insignificant coefficients, which further satisfies the parallel trend assumption. We also find that the positive effects of deregulation on borrowers are more pronounced in cities with higher Herfindahl-Hirschman Indexes (HHIs) ex-ante, showing that the bank branch expansion was more effective in previously less competitive areas.

In sum, deregulation led to two seemingly opposing effects on the economy. On the positive side, for individual private firms with bank credit access, deregulation improved firm growth and profitability, especially in previously less competitive banking areas. On the negative side, across all firms, deregulation led to more credit allocated to inefficient SOEs. This unintended worsening of credit allocation across firms undermined the positive effects of the 2009 deregulation. A backof-the-envelope calculation highlights the point: the total amount of credit misallocation to SOEs 
following the deregulation is approximately RMB674 billion, equivalent to $0.25 \%$ of annual GDP losses, while the positive effects of deregulation account for $0.97 \%$ GDP gains. ${ }^{7}$

This paper contributes to the literature in three ways. First, our findings add to the large literature on the nexus of financial market reform and economic growth, which has shown ambiguous associations between the two. ${ }^{8}$ Using comprehensive granular loan-level data, this paper documents loan-to-loan competition dynamics and disentangles the costs and benefits of deregulation in the context of the banking sector. Prior studies have shown that competition can have negative effects such as increased risks in the banking system (e.g., Keeley (1990); Allen and Gale (2000); Hellman, Murdock and Stiglitz (2000); J iang, Levine and Lin (2017)) and decreased efforts from banks in regard to loan screening and monitoring (e.g., Petersen and Rajan (1995); Boot and Thakor (2000); Marquez (2002)). We document a new consideration: deregulation leads to lending to inefficient SOEs. This worse credit allocation is primarily attributable to SOE's soft budget constraints and serves as a novel and nontrivial cost of banking deregulation in China. The closely related studies are by Gormley $(2010,2014)$, which show that new entrant foreign banks target a specific group of borrowers. Thus, productive firms are crowded out, and economic growth slows down consequently.

Second, our finding of this unintended adverse consequence has broad implications beyond China. The core of the first- and second-welfare theorem is that market competition can be beneficial, while under the theory of second-best, this might not be the case with market frictions.

\footnotetext{
7 See the detailed calculation for the aggregate effects of deregulation in Section 4.6. One potential caveat is that the Chinese government designed this deregulation to channel more credit towards SOEs. We find the opposite in the data, i.e., the shares of assets for SOEs are significantly smaller in deregulated cities than in the still regulated cities.

${ }_{8}$ Many studies have found positive relationships between financial market development and economic growth. See, for example, Gurley and Shaw (1955); Goldsmith (1969); McKinnon (1973); King and Levine (1993a, b); Demirgüç-Kunt and Maksimovic (1998); Rajan and Zingales (1998); Levine and Zervos (1998); Levine, Loayza and Beck (2000); Cetorelli (2003); Cetorelli and Strahan (2006); and Bertrand, Schoar and Thesmar (2007). In contrast, there are also opposing views and contrary evidence on the harmful effects of financial reform, especially in relation to banking reforms. See, for example, Petersen and Rajan (1994); Berger et al. (1998); Cetorelli (2001); Cetorelli and Gambera (2001); Prasad et al. (2003); and Hakenes and Schnabel (2010). Cetorelli and Peretto (2012) argue that the effects of bank competition depend on market conditions.
} 
Fixing one friction, e.g., bank entry restrictions, can introduce unintended adverse effects arising from other frictions, e.g., the soft budget constraints of SOEs. The consolidation of banks is a global phenomenon that has spurred much public debate (e.g., Berger, Demsetz and Strahan (1999)). Policymakers' decisions on banking reforms rely heavily on fully understanding economic consequences from all dimensions, especially for the interactions of different frictions in reform policies and the potential adverse effects. Additionally, governments should optimally sequence reforms to minimise risks and maximise benefits (e.g., Calvo (1998); Fischer (1998); Prasad et al. (2003); Chinn and Ito (2006), Kaminsky and Schmukler (2008)). ${ }^{9}$

Third, the literature has also shown that increased bank competition can lower borrowing costs and improve lending efficiency to fuel economic growth (e.g., J ayaratne and Strahan (1996, 1998); Smith (1998); Barth, Caprio and Levine (2001, 2004); Claessens, Demirgüç-Kunt and Huizinga (2001); Black and Strahan (2002); Dick and Lehnert (2010); Jiang, Levine and Lin (2016)). Our findings of positive effects of deregulation on individual borrowers align with this conventional wisdom. More importantly, we take a further step by illustrating both sides of such competition at the loan contract level: how new entrant banks target borrowers and change loan contract terms and how incumbent banks respond. ${ }^{10}$ In short, this paper is not only a simple study on treated vs. control groups but also a study on the industrial organization of the banking market, with spillovers depending on the local market and the identity types of banks and firms. The granular findings unveil the underlying mechanisms of the economic consequences of the banking deregulation documented in the literature.

Therest of this paper is organised as follows. Section 2 describes the institutional background of the banking system in China. Section 3 presents our data and summary statistics. Section 4

9 This suggestion echoes several recent studies arguing that reforms in China could have unintended adverse consequences (e.g., Hachem and Song (2016, 2017); Chen, Petukhov and Wang (2017); Liu, Wang and $\mathrm{Xu}$ (2017); Wang et al. (2017)).

10 Degryse and Ongena (2007) and Degryse, Laeven and Ongena (2009) also use granular loan level datasets to study the interbank competition with a focus on relationship lending and spatial pricing. This paper complements their studies from the perspective of changes in the industrial organisation of the banking sector. 
provides the empirical results regarding bank competition and its economic effects. Section 5 concludes.

\section{Background}

\subsection{China's Banking System}

The banking sector in China originated from a centralised system in 1949 when the People's Bank of China (PBOC), as China's central bank, governed both commercial bank businesses (e.g., deposits, lending, and foreign exchange) and central bank functions. Along with economic opening policies being instituted by Deng Xiaoping in 1978, the banking system entered a period of reform. In 1983, the PBOC began to focus on national macroeconomic policy, monetary stability, and economic development. At the same time, the big four commercial banks (i.e., the ICBC, ABC, BOC and, CCB) started to take over commercial bank businesses, and each was specialised in a specific area. ${ }^{11}$ In 1987, the Bank of Communications (BoCom) was formally established and became the first national shareholding commercial bank. We classify the ICBC, $\mathrm{ABC}, \mathrm{BOC}, \mathrm{CCB}$, and BoCom as the big five commercial banks in China directly controlled by the state. ${ }^{12}$ The two principal shareholders of these big five commencial banks are the Ministry of Finance and the China Investment Corporation. ${ }^{13}$

The Bank of Communications' experience in reform and development has paved the way for the development of shareholding commercial banks in China and exemplified banking reforms in China. Between 1988 and 2005, twelve joint equity banks were established, mostly as SOEs or institutions transformed from local financial companies. Although joint equity banks are also national banks, unlike big five commercial banks, they usually focus on local business and operate on a much smaller scale. This is partly the case because these joint equity banks cannot open

\footnotetext{
11 The Industrial and Commercial Bank of China (ICBC) specialised in credit business, the Agriculture Bank of China ( $\mathrm{ABC}$ ) specialised in supporting economic development in rural areas, the Bank of China (BOC) specialised in foreign exchange business, and the China Construction Bank (CCB) is responsible for the management and distribution of government funds allocated for construction and infrastructure projects. 12 We exclude the BoCom in the sample and find that our main results presented in this paper are robust.

13 The China Investment Corporation is a sovereign wealth fund that manages foreign exchange reserves.
} 
branches freely in cities other than cities in which they hold headquarters. Compared to the big five, joint equity banks play a much less central role in the banking market. For example, in 2006, the total assets of big five banks amounted to RMB 24.4 trillion while the total assets of joint equity banks amounted to RMB 5.4 trillion.

\subsection{CBRC Regulations on Bank Branch Openings}

As is the case in many other countries, the banking sector in China is heavily regulated. In March 2003, the CBRC was founded to supervise and monitor the banking sector. ${ }^{14}$ The CBRC placed strict restrictions on the twelve joint equity banks, especially with regard to the opening of new branches. In particular, in 2006, the CBRC announced that the twelve joint equity banks, along with local commercial banks, could only apply to open one branch in one city at a time with each application..$^{15}$ Specifically, banks cannot submit another branch opening request until the current one has been rejected or approved by the CBRC. A bank must send an application to the CBRC's provincial offices for initial review. When an application passes this local review, the case is then transferred to the CBRC's headquarters for final evaluation. The turnaround time for each application is approximately one year with some taking even longer, depending on the review periods of local CBRC offices.

Moreover, the CBRC capped the total number of branches that could be opened in each city. At the end of 2005, big five bank branches were on average operating in approximately $90 \%$ of Chinese cities while the twelve joint equity banks were operating in only approximately $7 \%$ of Chinese cities. The bank entry regulation imposed by the CBRC in 2006 greatly limited capacities of joint equity banks to compete fairly with big five banks that had already established branches in almost all cities and counties in China.

14 It was renamed as China Banking and Insurance Regulatory Commission (CBIRC) in 2018.

15 Please refer to CBRC Order [2006] No.2, titled "The implementation of administrative licensing items on Chinese commercial banks" 
In April 2009, "Adjustment comment on the market access policy of setting up branches for small- and medium-sized commercial banks" was introduced by the CBRC as a significant and vital policy deregulating the Chinese banking system. ${ }^{16}$ This adjustment aimed to freejoint equity banks by allowing them to open new branches in new cities. The deregulation removed the 2006 branch opening restriction in a city when a joint equity bank had already set up branches in this city. J oint equity banks can also enter all cities of a province freely when they had branches in the capital city of a given province. Explicitly, for these deregulated cities, joint equity banks can freely open branches without any restrictions on the number of branches opened. Moreover, for each application, joint equity banks can apply to open multiple branches without approval from the central CBRC office. Banks only need the approval of local CBRC office, rendering the application process much simpler and more efficient with typically four months of turnaround time.

Moreover, no specific requirement on capital amounts for new branches was imposed. However, when a bank did not operate any branches in a city or provincial capital city, it was still strictly regulated under the 2006 entry barrier of the CBRC. Taken together, this bank entry deregulation policy enacted in April 2009 would dramatically reduce the cost and waiting periods of new branch entry applications for joint equity banks. As one senior officer of the CBRC noted, the deregulation shock served as a milestone in the development of commercial banks and in growing levels of competition in China's banking sector. ${ }^{17}$ On October 15, 2013, in CBRC Order [2013] No.1, an updated version of CBRC Order [2006] No.2, the CBRC completely lifted entry restrictions placed on all banks.

In this paper, we use this 2009 partial deregulation policy as an exogenous shock to perform a standard Difference-in-Differences (DID) test. Specifically, the 2009 deregulation does not

16 Please refer to CBRC Order [2009] No. 143, titled "Adjustment comment on the market access policy of setting up branches for small- and medium-sized commercial banks"

17 In response to this deregulation, the China Merchants Bank, one of the twelve joint equity banks, decided to open another 20 new branches by the end of 2009. As reported in the Announcement of 39th Meetings of the Seventh Sections of The Board of Directors, the China Merchants Bank would expand to Jiangsu, Guangdong, Henan, Sichuan, Shandong, Zhejiang, Jiangxi, Liaoning, Fujian, Yunnan, Hunan, Hubei, Anhui, and Guangxi. 
apply to big five banks already operating in most cities in China. Big five banks operating in cities in which no joint equity banks are allowed to expand are not directly affected by the 2009 deregulation policy and thus can serve as the control group. This allows us to use DID regressions to identify various treatment effects of the deregulation on how new entrant joint equity banks compete ("intruders"), how big five banks respond ("defenders"), and how firms respond in deregulated cities relative to the control groups, respectively. Since this partial deregulation only applies to specific regions and banks, depending on banks' branch distributions before the shock, the exogenous variation in deregulation is at the bank-city-time level. For example, joint equity bank A is treated in city B if bank A established branches in city B (or in the provincial capital of city B) before April 2009, while joint equity bank $\mathrm{C}$ is not treated in city B if bank C did not have branches in city B (nor in the provincial capital of city B) before April 2009. We show detailed summary statistics of treatment vs. control groups in Section 3.4.

\section{Data and Summary Statistics}

We use three datasets for our empirical analyses, including two proprietary datasets on Chinese bank loans and branches and Chinese Industry Census (CIC) firm-level data.

\subsection{Loan Level Data}

The first dataset includes all major bank loans that the regulator compiled for monitoring and administrative use, covering over 7 million loan contracts granted by the 19 largest Chinese banks to firms with unique organisation codes. This monthly frequency dataset covers all borrowers with an annual credit line of over RMB 50 million (approximately US\$ 8 million) and covers the period running from October 2006 to J une 2013, which accounts for over $80 \%$ of all bank credit in China. The data cover over 160,000 borrowing firms located in all 31 provinces in China and 20 different sectors determined by the Economic Industrial Classification Code for China. In addition to their comprehensive coverage, the data also offer detailed loan-level information, i.e., the unique firm identifier, firm-level fundamentals (e.g., size, leverage and 
location), bank information (e.g., the names and location of branches), and loan-level characteristics (e.g., loan amounts, loan maturity levels, credit guarantee providers, issuing dates, loan maturity dates, and loan delinquency statuses). ${ }^{18}$ Specifically, for each loan, the data record the internal ratings at the monthly frequency, which allows us to trace the rating changes at the individual loan level over time.

\subsection{CBRC Branch Data}

The second dataset includes the information of all bank branches in China, which is also collected by the CBRC. This dataset covers over 200,000 branches of approximately 2,800 banking financial institutions for 1949 to 2016. The dataset includes branch level information, such as full names, branch IDs, branch addresses, and exact opening and closing dates. From these data, we can determine how many new branches a specific bank set up in a given period and in a particular region (provinces, cities, or counties). For our analyses, we restrict bank branch sample to the 17 commercial banks (i.e., big five banks and twelve joint equity banks).

To validate the quality of these bank branch data, we cross-check them with public branch information for the Bank of China (BOC) for 2016. We use data for the BOC because we can find information on all of its branches with corresponding names, addresses, branch levels, and operating statuses on BOC's website. We construct the BOC's branch list for September 2016 from the CBRC's dataset and check each of these branches based on the BOC's website. In total, the BOC's website records 10,714 operating branches. This number is close to the number of branches $(10,686)$ disclosed in the BOC's 2015 annual report and is also similar to the number reported in our CBRC dataset (10,678 branches). We also compare the names of branches between CBRC data and BOC's website, and 9,900 branches have the same names in these two datasets. This means that $92.7 \%$ of the branches reported in the CBRC dataset are the same as those listed on BOC's website. For the remaining 7.3\% unmatched branches, we manually checked their names at the

18 However, the data do not record loan interest rates. In China, the lending rate was fully liberalised after J uly 20, 2013. During our sample period, bank lending rates were still highly regulated. 
city level, and we can match another 3.6\% of the branches. In sum, $96.3 \%$ of BOC branches listed in the CBRC dataset can be matched to branches listed on BOC's website. The quality of the CBRC bank branch dataset is thus outstanding.

\subsection{Chinese Industry Census Data}

The third dataset we use for this study is the CIC for 1998 to 2013.19 The CIC was collected by the Chinese National Bureau of Statistics (NBS). It covers all manufacturing firms in China with annual sales of more than RMB 5 million (this increased to RMB 20 million in 2011). The CIC appears to be the most detailed database on Chinese manufacturing firms, and the content and quality of the database are sufficient. The CIC offers detailed firm-level accounting information (e.g., balance sheets, income statements, and cash flow statements) as well as other firm characteristics (e.g., number of workers, locations, industries, shareholder types, and registration types). To investigate the impact of bank credit access on firm activities, we merge CBRC data with CIC data by unique firm IDs for 2007 to 2013. Although we do not have access to loan-level interest rate information from CBRC loan data, we take the values of firm annual interest payments in CIC data and divide them by the total amounts of loans outstanding at the prior year to calculate the interest rate at the firm-year level. From firm registration types given in CIC data, we classify firms as SOEs and private firms.

We also obtain population census data on all firms in China for 2008. This cross-sectional dataset records firm IDs, total assets, ownership information, numbers of workers, and operating incomes for 9,212,411 firms. Approximately 75\% of the firms included in the CBRC dataset can be matched to the 2008 census data (i.e., twelve thousand of sixteen thousand). ${ }^{20} \mathrm{We}$, in turn,

\footnotetext{
${ }_{19}$ We obtained CIC data for 1998 to 2013 with the exception of data for 2010, which are of poor quality. For 2010 we use Orbis data from Bureau van Dijk to compensate for firm variables of the CIC. We in turn recover approximately $80 \%$ of the data for 2010 .

20 We cross-checked the variables between CIC and 2008 census data. More than $95 \%$ of them are consistent. In CBRC data we compared differences in firm characteristics (e.g., total assets) of firms matched to the census and unmatched firms. The t-tests show insignificant differences.
} 
stratify CBRC borrowers by ownership (i.e., SOEs vs. private firms) and performance features (e.g., high vs. low efficiency).

\subsection{Summary Statistics}

Figure A1 in the Appendix shows two heat maps illustrating the number of outstanding joint equity bank branches operating in 2008 and 2013. The darker colour corresponds to a larger number of joint equity bank branches operating in a province. Over the last two decades, joint equity banks have been proliferating. As is shown in Panel A of Figure A1, in 2008, there were still several provinces with less than 20 joint equity bank branches (J ilin, Inner Mongolia, Gansu, Qinghai, Ningxia, Guizhou, Guangxi, Hainan, and Xizang). Overall, in 2008, the big five banks dominated China's banking system with 51,557 branches operating in $84.9 \%$ of Chinese cities while the twelve joint equity banks were suppressed severely in terms of competition with only 4,161 branches operating in 9.5\% of Chinese cities. After the 2009 deregulation, the number of joint equity bank branches increased dramatically from 4,161 in 2008 to 5,272 in 2010, covering $15.7 \%$ of Chinese cities, while the big five barely expanded their coverage (by only a $2 \%$ increase) over the same period. Moreover, Panel B of Figure A1 shows that 12 out of 31 provinces had over 200 joint equity bank branches by the end of 2013. Notably, five provinces reached over 500 joint equity bank branches, i.e., Guangdong, Zhejiang, Shandong, Shanghai, and Jiangsu. In Figure A2 of the Appendix, we plot the number of big five bank branches operating in 2008 and 2013. Again, the numbers did not change considerably during these five years.

In addition to the increase in the number of branches observed, joint equity banks also grew rapidly in terms of lending market shares. In particular, in Figure A3 in the Appendix, the dotted line represents the percentage of joint equity banks' loans outstanding of total loans outstanding (i.e., joint equity and big five banks). The number has increased over time. For example, in 2007, $21.7 \%$ of outstanding loans were issued by joint equity banks. This number increased to $24.5 \%$ in 2008 and sharply jumped after the 2009 deregulation, reaching 33.5\% in 2010. This confirms that joint equity banks expanded substantially following deregulation. The share of joint equity 
banks continues to increase over time (i.e., from $21.7 \%$ in 2007 to $40.1 \%$ in 2013, an increase of approximately 85\%). Moreover, the solid line represents shares of joint equity banks for new loan issuances, revealing similar patterns as the dotted line.

To further illustrate contributions of the 2009 deregulation policy to the rapid catching up of joint equity banks, in Figure A4 in the Appendix, we plot the unconditional pattern for loans outstanding for treated joint equity banks in their deregulated cities and control groups (i.e., big five banks in cities not affected by the shock). The solid line represents the treatment group, and the dotted line represents the control group. Before April 2009, loans outstanding for the treatment group changed in parallel with loans outstanding for the control groups. Since the deregulation shock in April 2009, the gap has been increasing over time because joint equity banks can freely open new branches in deregulated areas. The pattern illustrated in Figure A4 suggests that the increased lending after April 2009 was mainly due to deregulation. No significant changes in differences between the treatment and control cities are found before April 2009. This serves as evidence of a parallel trend assumption underlying the DID analysis.

Table 1 presents summary statistics for the data. As discussed above, we study the impacts of the 2009 bank entry deregulation policy. Our main variable of interest is the DID dummy After2009.4×Exposure, where After2009.4 is equal to one for observations following the policy shock of April 2009 and is equal to zero before it. We begin the analysis on one of the treatment groups: joint equity banks in their deregulated cities. In particular, for joint equity banks, Exposure is equal to one in city $\mathrm{j}$ where a bank has existing branches or in the capital city of the province of this city since, according to the 2009 deregulation policy, this joint bank is free to open branches in city j. Exposure is equal to zero for the control group for big five banks in cities where no joint equity banks are allowed to expand. We exclude cities in which joint equity banks hold headquarters in the sample since all twelve joint equity banks have opened a significant 
number of branches in cities in which they hold headquarters and did not need to expand more after the deregulation policy. ${ }^{21}$

Panel A reports city-bank-month descriptive statistics with 332,904 observations. The mean of Exposure is 0.533, which means that, on average, 53.3\% of the city-bank pairs are affected by deregulation while the other $46.7 \%$ are not directly affected. Moreover, among the city-bank pairs with Exposure=1, 18.7\% of them operated joint equity bank branches before April 2009. In other words, for the remaining $81.3 \%$ of the cities, unrestricted branch opening occurred due to there being existing branches in provincial capital cities rather than in the city itself. ${ }^{22}$ This mitigates concerns over whether the government endogenously targeted several specific cities to perform deregulation in 2009. Panel A also reports the number of branches and loans outstanding at the bank-city-month level for 2007 to 2013. On average, each bank operates 1.37 branches in each city. This is a small value due mainly to the fact that joint equity banks operate no branches in many cities, especially in earlier years.

Panel B presents a summary of loan contract terms. The average loan is valued at approximately RMB 14.8 million with short-term maturity. In total, $99.1 \%$ of the loans have the highest ratings at the point of issuance. Approximately $24.1 \%$ of loans have third-party guarantees, which provides a credit enhancement scheme for lenders. The default rate defined as over 90 days of delinquency is $0.9 \%$, and this is comparable to the nonperforming loan rate disclosed in banks' annual reports in China. For each loan, we also know the borrower's characteristics, such as total assets, leverages, ownership information. Panel C shows firm-level characteristics observed after merging CBRC borrowers with CIC data. For example, the median firm size is RMB 198.6 million. We measure firm efficiency by total-factor productivity (TFP), which is calculated from the CobbDouglas function by taking the residual in the regression of the log(total revenue) on log(total

21 Our empirical results remain qualitatively and quantitatively robust even when we include observations of cities in which banks hold headquarters.

22 Table A2 of the Appendix lists the branch numbers of different banks operating across provinces before the 2009 deregulation. 
assets) and log(total employment) in the CIC firm panel data from 1998 to 2013. We describe all variable definitions in Table A1 of the Appendix.

\section{[Place Table 1 about here]}

\section{Empirical Analysis and Results}

\subsection{Expansion of J oint Equity Banks under 2009 Deregulation}

We start by analysing how joint equity banks expand in terms of opening new branches and making loan issuances after the 2009 deregulation. In other words, we examine if joint equity banks expand and compete with incumbent big five banks in the lending market when the restrictions on branch openings are removed. Following deregulation, joint equity banks can freely open branches in the cities in which they already established branches or in all cities of a province in which they operate branches in the capital city of that province. At the city-bankmonth level, we regress the number of branches and outstanding loan amounts on the 2009 deregulation shock. Formally, the regression can be expressed as follows:

$$
\begin{aligned}
& \mathrm{Y}_{i j t}=\beta_{1} \times \text { After } 2009.4_{t} \times \text { Exposure }_{i j}+\beta_{2} \times \text { After } 2009.4_{t} \\
& \quad+\beta_{3} \times \text { Exposure }_{i j}+\phi X_{i t}+\alpha_{i}+\delta_{j}+\eta_{t}+\varepsilon
\end{aligned}
$$

where $\mathrm{Y}_{i j t}$ is the logarithm of one plus the number of outstanding branches or the logarithm of one plus the total value of outstanding loans for city $\mathrm{i}$, bank $\mathrm{j}$ at the end of month $\mathrm{t}$. Exposure $_{i j}$ is equal to one for joint equity banks in deregulated cities and is equal to zero for the control group. We control for city $\left(\alpha_{i}\right)$, bank $\left(\delta_{j}\right)$, and year $\left(\eta_{t}\right)$ fixed effects. We also control for a city's GDP each year. Moreover, we exclude the cities in which joint equity banks in the sample hold headquarters since all twelve joint equity banks have built a substantial number of branches in cities where they hold headquarters and do not need to expand more after deregulation.

Table 2 shows the regression results. The dependent variable in Panel A is the logarithm of one plus the number of outstanding branches. Column (1) applies to the period three months before and after the shock (i.e., from J anuary 2009 to J une 2009). Columns (2), (3), and (4) apply 
to periods six months, twelve months, and twenty-four months before and after the shock, respectively. Consistent with the unconditional patterns in Figure A1, in columns (1) to (4) the coefficients $\beta_{1}$ of After2009.4×Exposure are positive and statistically significant. For example, in column (1), the coefficient is 0.007 with a t-statistic of 4.94 . This means that deregulation led to a $0.7 \%$ increase in the number of joint equity bank branches in deregulated cities three months after the shock. Additionally, the coefficients of After2009.4×Exposure increase monotonically from columns (1) to (4). For example, in column (4), the coefficient is 0.086 with a t-statistic of 17.13. This means that the number of joint equity bank branches increased by $8.6 \%$ in deregulated cities two years after deregulation. The long-term effect of deregulation on joint equity bank branch expansion is larger since it takes time to open branches in a new city. ${ }^{23}$ In short, following deregulation, joint equity banks indeed open significantly more branches in the new market, as anticipated. Although the branch opening decisions are endogenous, our DID estimator uses exogenous variation from the deregulation policy and estimate the average effects of deregulation, which is the standard approach in the literature (e.g., J ayaratne and Strahan (1996)).

In Panel B of Table 2, the dependent variable is the logarithm of one plus outstanding loan amounts. Consistent with the unconditional patterns in Figures 2 and 3, deregulation led to a significant increase in lending from joint equity banks in deregulated cities. For example, the coefficient estimated in column (4) is 0.312 (t-statistic=17.63) statistically significant at the $1 \%$ level, which means that the total value of outstanding loans increased by $31.2 \%$ due to deregulation. These effects are economically significant. Furthermore, as robustness checks, the results are still consistent after controlling for the city $\times y e a r$ and bank $\times$ year fixed effects.

\section{[Place Table 2 about here]}

\footnotetext{
23 This also mitigates concerns that for still regulated cities, joint equity banks can simply open one branch to be qualified for the deregulation. Furthermore, we find that when a joint equity bank did not operate any branches in a city (nor in the provincial capital city) before April 2009, the bank could not qualify for deregulation even when it opened a branch subsequently.
} 
Next, we study another treatment effect on how the incumbent big five banks respond to the deregulation shock. In Appendix Table A5, we repeat the regressions of loans outstanding and the number of branches operated by bigfive banks. The control group includes big five banks operated in still regulated cities after April 2009. In particular, Exposure is equal to one for big five banks in deregulated cities and is equal to zero for big five banks in regulated cities. The coefficients of After2009.4×Exposure are statistically insignificant. In sum, after deregulation, incumbent big five banks barely change their lending practices in deregulated cities while joint equity banks expand considerably. These results are consistent with the unconditional patterns shown in Figures 1, 2, and A1. In short, the 2009 deregulation led to a significant growth in the joint equity banks' market share and to enhanced competitive pressures on incumbent big five banks, which is in line with the goals of deregulation.

The deregulation shock may be confounded with the RMB 4 trillion stimulus package initiated in November 2008. For example, the RMB 4 trillion program could have granted more credit for deregulated cities than for regulated ones. To mitigate this concern, in Table A3 we calculate the growth rates of loans outstanding for November 2008 to March 2009 (i.e., after the RMB 4 trillion but before the 2009 bank entry deregulation) for joint equity banks operating in deregulated cities, big five banks operating in deregulated cities, and big five banks operating in still regulated cities (i.e., control groups). Table A3 shows that the average growth rates of outstanding loans amount are approximately $30 \%$ for all three groups. We perform t-tests on each pair of these three groups and document insignificant differences within each pair. Moreover, in column (1) of Table 2, we restrict our sample to J anuary 2009 to J une 2009 (within the RMB 4 trillion period), and we continue to find that the 2009 deregulation helped joint equity banks expand in deregulated cities. These results suggest that increases in lending observed between the treatment and control groups from our DID analysis do not confound with the RMB 4 trillion program and move in parallel before the deregulation policy of April 2009. 
In addition to our analyses of deregulation effects on lending activities in Table 2, we also examine how these new entrant branches affect deposits made in local areas since the economic consequences can also come from the depositor's side. In Table A6, we perform DID regressions using local deposit values as the dependent variable. The coefficients of After2009×Exposure are mostly insignificant. In China, the deposit interest rates are capped by the government during our sample period so that new entrant banks provide local depositors the same interest rates as incumbent banks. Consequently, the depositors have weak incentives to switch banks. This may explain why the 2009 deregulation has had enormous impacts on lending activities but less so for deposits. In short, competition is not at the level of deposit mobilization following deregulation, and our analysis of the deregulation policy's economic consequences in Section 4.3 primarily relates to the lending side.

\subsection{Banking Deregulation and Credit Allocation}

Next, we aim to explore, following deregulation, where the increased credit from entrant banks flowed to. In particular, we study how joint equity banks alter their credit allocation patterns after the 2009 deregulation shock. It is well documented that in China, banking credit allocation is inefficient since commercial banks (both big five and twelvejoint equity banks) prefer to lend to SOEs. ${ }^{24}$ This is mainly the case due to government intervention and the soft budget constraints of SOEs. SOEs have been enjoying government guarantees, which provides them with easy access to credit from banks as most SOEs maintain excessive employment. Private firms, on the other hand, have minimal access to bank credit.

To understand the effects of deregulation on credit allocation, we calculate both the total outstanding loans to SOEs and the ratio of loans made to SOEs to total loan amounts for each city-bank-month as a dependent variable in the DID regressions. Table 3 shows that joint equity

24 For example, based on the estimate in our sample, SOEs contribute $9 \%$ of the output in China while they take $22 \%$ of the bank credit. 
banks issue significantly more loans to SOEs after the 2009 deregulation in deregulated cities in which they can open branches freely. Columns (1) to (3) use the logarithm of the outstanding loan amount for SOEs as our dependent variable in our DID regressions. For example, in column (1), we restrict our sample to one year before and after the shock (i.e., two years in total). The coefficient of After2009.4×Exposure is 0.393 with significance at the $5 \%$ level. This means that joint equity banks increase their total lending to SOEs by 39.3\% in the first year following the deregulation in deregulated cities. In column (2), for the period two years before and after the shock, the coefficient of After2009.4 $\times$ Exposure is 0.335 with significance at the $10 \%$ level, which is smaller than 0.393, and the coefficient becomes statistically insignificant in column (3) for the whole period from 2007 to 2013.

Moreover, in columns (4) to (6), we use the ratio of loans made to SOEs over total loan amounts as the dependent variable in our DID regressions. Consistent with columns (1) to (3), the coefficients of After2009.4×Exposure are significantly positive within the two-years window. For example, in column (4), the coefficient of After2009.4 $\times$ Exposure is 0.053 with significance at the $5 \%$ level. Approximately $28.5 \%$ of the loans outstanding from joint equity banks were for SOEs in 2008. This means that, on average, in the first year following deregulation, joint equity banks increased their shares of lending to SOEs by $18.6 \%(0.053 / 0.285)$. The coefficient of After2009.4×Exposure in column (5) is 0.045 with significance at the $10 \%$ level, which is smaller than 0.053 in column (4) and is equivalent to a $15.8 \%$ increase in lending shares to SOEs in two years after deregulation. Moreover, e column (6) is for the entire period in our data (i.e., from 2007 to 2013) and the coefficient of After2009.4×Exposure is statistically insignificant. The pattern in columns (4) to (6) again implies that although the credit distortion to SOEs is significant following deregulation, it is short-term (i.e., within two years).

[Place Table 3 about here] 
In addition to new entrant joint equity banks, we also study the treatment effect of deregulation on incumbent big five banks in terms of their credit allocation patterns. We repeat these DID regressions for big five banks in Table A8 of the Appendix. From columns (1) to (6), all coefficients of After2009.4×Exposureare statistically insignificant. This means that bigfive banks did not respond much to deregulation in regard to their SOE lending so that the increases in SOE lending from joint equity banks after the 2009 deregulation did not crowd out SOE lending from incumbent big five banks.

Overall, the 2009 deregulation led to more bank credit given to SOEs. It is well documented that in general, SOEs are less efficient than private firms. ${ }^{25}$ The 2009 bank entry deregulation thus led to an unintended worsening of credit allocation in China. One potential alternative story is that, instead of interpreting the credit misallocation as unintended, the Chinese government designed this deregulation to channel more credit towards SOEs. However, we find the opposite in the data. In particular, we calculate the SOE asset share (i.e., the total assets for all SOEs divided by the total assets of all firms in a city) before the deregulation using the 2008 Census data. We find that the SOE asset share weighs less (32.5\%) in deregulated cities than the still regulated ones (41.4\%). The difference is statistically significant at the $1 \%$ level.

The key assumption of our DID analysis is the presence of parallel trends between the treatment and control groups. In columns (2) and (4) of Panels A and B, we include three pretrend dummies to refer to January, February, and March of 2009 (i.e., three months before the deregulation shock). All pretrend dummies have insignificant coefficients. This again verifies that our DID findings are not driven by underlying economic trends other than by the deregulation policy of April 2009. Furthermore, in Table A10 of the Appendix, we perform the same analysis as that given in column (2) and (5) of Table 3, but we include dummies Exposure $\times$ Month $_{t}(\mathrm{t}$

${ }^{25}$ Consistent with prior studies, in Table A9, Panel A we show that SOEs are significantly less efficient than private firms in China. In particular, we use the asset turnover ratio (sales/assets) and TFP to measure efficiency and find that these two variables are significantly lower for SOEs than for private firms. 
covers April 2008 to March 2010). We find that before April 2009, all coefficients of dummies Exposure $\times$ Month $_{t}$ are statistically insignificant. After April 2009, we have significantly positive coefficients for dummies Exposure $\times$ Month $_{t}$. This serves as strong evidence of the parallel trend assumption and that the shock did have impacts after April 2009.

Another caveat of our DID method is that the banks in control group might also be affected by the deregulation indirectly. For example, although big five banks in the cities where no equity banks are allowed to enter following deregulation do not face new competitors in these regulated cities, there could be spillover effects from their other branches from deregulated cities. We find that big five banks do not respond significantly even in deregulated cities in regards to the lending amount (Table A5) and SOE loans (Table A8), which mitigate the concerns about spillovers.

\subsection{Reasons for the Credit Misallocation from New Entrant Banks}

In this section, we further explore the underlying rationales behind the credit distortion to SOEs following deregulation. Our hypothesis is that when a joint equity bank enters into a new city, relative to incumbent big five banks, it usually does not have access to ample information on local firms. With this information threshold, these new banks prefer to lend to SOEs, which have soft budget constraints with implicit or explicit government guarantees. When these entrant banks accumulate more information on local firms, they start to increase lending to more productive private firms in the long run, as we find in Section 4.2.

To support this hypothesis, we first explore how new entrant branches select borrowers among SOEs. In Table 4, we calculate the TFP for each firm before the shock (i.e., for 2008). We then use the TFP to measure firm efficiency, and we define an efficient firm as one with a TFP value above the median. In columns (1) to (3), among SOEs, we calculate the percentage of loans made to SOEs with high TFP as the dependent variable at the city-bank-month level and perform DID regressions. Column (1) is for one year before and after the deregulation, the coefficient of After2009.4 Exposure is -0.047 with significance at the $5 \%$ level, which is equivalent to a $4.7 \%$ 
increase in lending to inefficient SOEs. Moreover, in column (2), the coefficient of After2009.4×Exposure is also significantly negative for the two years window, while it becomes insignificant in column (3) for the entire sample period. This pattern is consistent with Table 3, suggesting that in addition to joint equity banks' preferences for SOEs, they further choose to lend to less efficient SOEs following deregulation in the short run.

\section{[Place Table 4 about here]}

We further explore the reason for the preference for inefficient SOEs. From Panel B of Table A9, we find that inefficient SOEs have significantly higher ranks in political hierarchy and significantly larger sizes. In China, different SOEs have different political ranks (e.g., local vs. central SOEs) and SOEs ranked higher usually have softer budget constraints. Similarly, larger SOEs enjoy softer budget constraints due to social stability concerns and the notion of being "too big to fail". In columns (4) to (6) of Table 4, we perform the same analysis on private firms and find no significant results since private firms do not have soft budget constraints, and banks have no apparent reason to lend to inefficient private firms. These results support our hypothesis that new entrant joint equity banks tend to lend to SOEs, especially to those inefficient ones since they are safer assets due to the stronger government guarantees.

Second, we use the monthly internal ratings of each loan in the sample to measure banks' information on borrowers. In particular, the loan data record the monthly internal ratings for each loan so that we can trace the rating changes over time. Conditional on delinquent loans, we observe whether the banks foresee the delinquency and downgrade ratings before the actual late payments (we call it as "early downgrade"). If banks have better information on certain borrowers, they can early downgrade the internal ratings for risk management. We use the early downgrade as the measure of banks' information on borrowers. In Table 5 Panel A, column (1) shows that banks can predict approximately $22.6 \%$ of the delinquency events within two years after branch opening, while this ratio increases to $42.3 \%$ after the third year. Moreover, as shown in column (2), we find that on average, banks can predict delinquency events 4.63 months before the actual 
late payments within two years after branch opening, and this length increases to 5.39 months after the third year.

\section{[Place Table 5 about here]}

These findings suggest that new entrant banks indeed lack sufficient information on local borrowers at the beginning but accumulate more and more information over time. They can predict the delinquent events more accurately and earlier after the third year of the branch opening. This matches the dynamics of credit misallocation, as documented in Table 3 and 4 . In summary, the soft budget constraints of SOEs generated an information threshold, below which SOE lending dominated lending to contemporaneously opaque local private firms. Moreover, SOEs in China typically have lower uncertainty in productivities than private firms. New entrant banks need to collect such information via due diligence, which could be time consuming. When these entrant banks accumulate more information on local firms, they start to increase lending to more productive ones in the long-run, and the short-term credit misallocation is gradually corrected, as we find in the data. This explains the short-run credit misallocation following deregulation.

\subsection{Banking Deregulation and Loan Contract Terms and Performance}

Next, we study changes in loan contract terms and loan performance observed for new entrant joint equity banks following deregulation. We begin the analysis by looking at the unconditional patterns. In particular, we define new entrant branches as those that open in less than or equal to 12 months in a city and categorise bank branches into incumbent vs. new branches. We then compare the loan contract terms of new entrant and incumbent banks. Table A4 of the Appendix reports the mean difference in loan contract characteristics. Panel A applies to all banks in the sample, and Panel B applies to joint equity banks. Patterns observed are very similar between Panels A and B. In particular, loans from new entrant bank branches are significantly larger, have better internal ratings, more third-party guarantees, and lower default rates. 
Besides the unconditional patterns, we perform a DID analysis at the loan level to assess causal effects of the 2009 deregulation shock on the loan contract terms of joint equity bank loans in deregulated cities. Formally, the regression is:

$$
\begin{aligned}
& \text { Loan Terms }_{\text {lkijt }}=\beta_{1} \times \text { After2009. } 4_{t} \times \text { Exposure }_{i j}+\beta_{2} \times \text { After } 2009.4_{t} \\
& +\beta_{3} \times \text { Exposure }_{i j}+\text { Pretrend }+\phi X_{k t}+\alpha_{j}+\delta_{k}+\eta_{t}+\varepsilon
\end{aligned}
$$

where Loan Terms lkijt refers to the characteristics of a loan $\mathrm{l}$ borrowed by firm $\mathrm{k}$ (located in city i) from bankj in month t. $\alpha_{j}, \delta_{k}$ and $\eta_{t}$ are vectors of bank, firm, and year dummy variables that account for bank-, firm-, and year-fixed effects. $X_{k t}$ is a set of time-varying firm-level variables, including the firm size and firm leverage ratio. The regression is at the individual loan issuance level. The coefficient of interest, $\beta_{1}$, estimates the impact of branch deregulation on loan contract terms. Standard errors are clustered at the firm level.

Table 6 Panel A shows the results. Columns (1) to (3) apply to private firms in our sample, and columns (4) to (6) apply to SOEs. Column (1) reports the effects of deregulation on loan ratings at the issuance. The coefficient of After2009.4×Exposure is 0.008 with significance at the $1 \%$ level, suggesting that loans with the best ratings increased by $0.8 \%$ after the deregulation shock. Column (4) refers to SOE loan ratings at the issuance, and the coefficient is insignificant. Column (2) is for third-party loan guarantees, and the coefficient of After2009.4×Exposure is 0.017 with significance at the $1 \%$ level. The average third-party guarantee ratio is $20.4 \%$, which means that deregulation led to an increase in third-party guarantees by $8.7 \%$. Moreover, for SOEs in column (5), the coefficient of After2009.4×Exposure is again insignificant. In short, following deregulation, entrant joint equity banks raised loan screening standards with significantly higher ratings and more guarantees in deregulated cities. This change is only observed for private firms and does not exist for SOEs.

There may be two reasons for the rating improvements: banks screen for borrowers with higher levels of credit quality, or banks inflate the ratings. Column (3) reports the effects of 
deregulation on ex-post loan default rates and the coefficient of After2009.4×Exposure is -0.005 with significance at the $10 \%$ level. On average, the default rate is approximately $0.8 \%$ for private firms, and -0.005 is equivalent to a $62.5 \%$ decrease in default. Column (6) refers to SOE loan default rates, and the coefficient is insignificant. This suggests that following deregulation, loan performance improved for private firms but not for SOEs in deregulated cities and supports the interpretation that entrant equity banks raised the screening bar and lent to borrowers of better credit quality.

\section{[Place Table 6 about here]}

In summary, the finding of higher screening standards for private firms but SOEs echoes our hypothesis behind the worsening credit allocation following deregulation. Specifically, for private firms, the new entrant joint equity banks require higher internal loan ratings and more thirdparty guarantees to mitigate the information disadvantage and reduce credit risks, while it is not necessary for SOEs due to their soft budget constraints (i.e., implicit government guarantees). These stringent lending standards for private firms can help joint equity banks to tease out private firms with credit constraints but of good quality, which leads to better loan performance.

\subsection{Beneficial Impacts following Deregulation}

This section explores the economic consequences of the 2009 bank entry deregulation in terms of firm activities. The 2009 deregulation policy on bank entry, along with other reforms of the financial system, aims to improve lending efficiency and promote economic growth in China. It is well documented in the literature that increased interbank competition leads to lower borrowing costs and thus higher economic growth. As discussed in Section 3.3, although we do not have access to loan-level information on interest rates, wecan back out such information from the interest payment amount documented in CIC data and the outstanding loan amount given in the loan data. 
In Table A7 Panel A in the Appendix, we find that deregulation significantly reduced borrowers' interest rates. In Panel B, we interact the DID dummy with the private firm dummy. We find that interest rates dropped significantly more for private firms than for SOEs. In particular, column (2) of Panel B shows that the coefficient of After2009.4×Exposure is -0.610, which is statistically insignificant. The coefficient of PrivatexAfter2009.4 $\times$ Exposure is -0.603 at the $1 \%$ significance level. The median interest rate is $9.1 \%$ in the CIC data. These results suggest that interest rates on average decreased by $6.6 \%$ for private firms after the 2009 deregulation. There is no significant effect on SOEs' borrowing costs. One caveat is that our interest rate calculation might not be accurate since interest payments given by the CIC may include interest for forms of debt other than bank loans or may exclude interest payments for fixed assets. To mitigate this concern, we collect a subsample of loans with accurate loan-level interest rate information for listed firms from the China Stock Market \& Accounting Research (CSMAR) database. Panel $\mathrm{C}$ shows that deregulation led to a significant decline in interest rates of loans based on the smaller sample in CSMAR.

Next, we wish to understand how firms respond to the 2009 deregulation in terms of securing lower borrowing costs. By merging the CIC firm-level data and the loan data, we select firms that have borrowed from banks in our sample period. These firms are directly affected by the 2009 entry deregulation. We then perform DID regressions of firm activities (e.g., expansions of assets and employment) and firm performance (e.g., net income and ROA) on the 2009 deregulation shock. The panel data are at the firm xyear level. The regression is as follows:

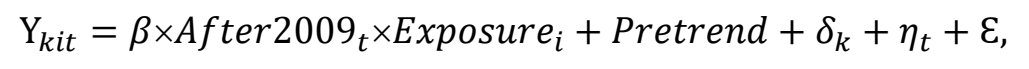

where $\mathrm{Y}_{k i t}$ is a vector of firm-level activities such as the growth of fixed assets and employment, leverage ratios, ROA, and growth in net incomes for firm $\mathrm{k}$ that is located in city $\mathrm{i}$ in

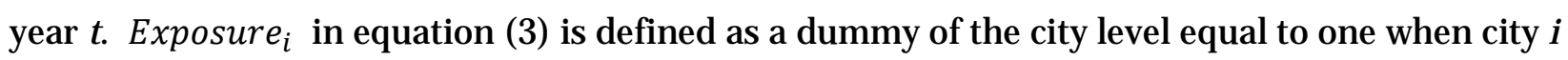
is eligible for branch expansion for any joint equity bank according to the 2009 deregulation (i.e., joint equity banks had already set up branches in city $i$ or in its capital city before the shock). We 
also control for the pretrend dummy for one and two years before the 2009 deregulation. $\delta_{k}$ and $\eta_{t}$ are included to account for the firm- and year-fixed effects. Standard errors are clustered at the firm level.

Table 7 shows the DID regression results. Overall, the 2009 joint equity banking sector deregulation does have significantly positive effects on firms' activities. For example, following the 2009 deregulation, firms in deregulated areas experienced significant increases in the growth rates of fixed assets and employment. In particular, column (1) shows that from 2006 to 2011 (i.e., three years before and after the shock), the growth rate of fixed assets on average increased by $34.1 \%$ with a t-statistic of 6.42 following the 2009 deregulation. In column (2) we expand our sample period from 2004 to 2013 (i.e., five years before and after the shock), and accordingly, the growth rate of fixed assets increased by $21.3 \%$ with a t-statistic of 5.65. Columns (3) and (4) refer to employment growth rates. The 2009 bank deregulation led to a $14.8 \%$ increase in firms' employment growth. Moreover, the coefficients of parallel trend interaction dummies Pretrend $_{t-1}$ and Pretrend $d_{t-2}$ are statistically insignificant. No significant differences in firm activities are observed between deregulated and regulated areas before the 2009 shock. This serves as more supportive evidence of the parallel trend assumption, which further mitigates the concern that the DID results are driven by the demand side of the economy (e.g., firms in deregulated cities have better investment opportunities).

From columns (5) to (8), we use net income growth and ROA to measure firm-level profitability and efficiency. The coefficient of After2009.4×Exposure estimated in column (5) is 0.872 with a t-statistic of 4.27 , showing that the net income growth rate increases by $87.2 \%$ after the 2009 joint equity bank expansion shock. In column (7), for ROA, the coefficient is 0.019 with at-statistic of 6.45. Since the average ROA of CIC firms is 0.061 , based on the coefficient estimated in column (7), the 2009 deregulation led to a 31.1\% increase in ROA.

[Place Table 7 about here] 
Furthermore, we trace the heterogeneous impacts of increased bank competition between SOEs and private firms. In particular, in Table 8, we interact the DID dummy with the dummy for private firms. Overall, private firms can benefit significantly more from the 2009 deregulation than SOEs can. The effects of the 2009 deregulation on SOEs are nearly absent. In particular, compared with SOEs, after the deregulation, private firms operating in deregulated cities presented significantly higher levels of fixed asset growth, employment growth, net income growth, and ROA. These effects are not statistically significant for SOEs. For example, in column (2), the coefficient of After2009.4×ExposurexPrivate is 0.336 with a t-statistic of 4.05 . This suggests that compared to those of SOEs, the fixed assets growth rates of private firms increase by $33.6 \%$ following the 2009 deregulation. On the other hand, the coefficient of After2009.4×Exposure is -0.117, which is statistically insignificant. This shows that in contrast to private firms, the 2009 deregulation has no impacts on SOE asset growth. Columns (3) and (4) also show similar patterns for employment growth.

Moreover, for firm performance (i.e., net income growth and ROA), private firms can also benefit significantly more from the 2009 deregulation, while SOEs did not increase their net incomes and ROA. Columns (6) and (8) show that, for private firms, the 2009 deregulation led to increases in net income growth and ROA by $91.8 \%$ and $21.6 \%(0.026 / 0.1201$ since the average ROA of private firms is $12.01 \%$ ), respectively. These findings suggest that expansions of joint equity banks in China have more positive effects on private firms since these firms are more efficient and can better capture the benefits of this reform. This is also consistent with Table A7, which shows that interest rates dropped more for private firm loans following the 2009 deregulation.

\section{[Place Table 8 about here]}

In summary, Table 7 and 8 show that for firms with bank credit access, increased bank competition has immediate and immense positive effects on their growth and performance. These positive effects are both statistically and economically significant and come mainly from private 
firms rather than SOEs. This suggests that credit not granted to more productive private firms was not used productively, in some sense "lost", emphasizing the potential unintended adverse consequences of banking deregulation in China.

Lastly, we explore the heterogeneous effects of deregulation across cities. In particular, new entrant banks should have more substantial impacts on areas with limited competition among banks before the shock. In other words, new entrant banks do not change the landscapes of the banking markets when they are already very competitive. We calculate the HHI based on the outstanding number of branches before the shock (i.e., in 2008) for each city. We then interact this ex-ante HHI with After2009.4×Exposure and repeat the DID regressions as shown in Table 7. Table 9 shows the regression results. The positive effects of the 2009 deregulation on borrowers are significantly more pronounced in cities with lower competition levels ex-ante (i.e., higher HHI). Interaction term After2009.4×ExposurexHHI presents significantly positive coefficients in most columns. For example, in column (1), the coefficient of After2009.4×Exposure $\times H H I$ is 1.542 with a t-statistic of 1.94, while the coefficient of After2009.4xExposure is 0.247 with a tstatistic of 3.43. This suggests that the asset growth rate is $9.1 \%$ higher for the least competitive cities than it is for the most competitive ones. ${ }^{26}$

\section{[Place Table 9 about here]}

\subsection{Quantifying the Positive and Negative Effects of Deregulation}

We show above that, on the one hand, the 2009 bank entry deregulation increased interbank competition and altered the local industrial organisation of banks. This led to significantly lower borrowing costs that caused borrowers to grow faster and to become more profitable. On the other hand, the benefits were adversely mitigated by a preference for lending to state-owned enterprises (SOEs) over more productive private firms. Understanding and disentangling these two opposing

\footnotetext{
${ }^{26}$ In addition to heterogeneous effects observed across cities with different levels of competition, we also explore new entrant banks' sizes. From unreported results, we find that the positive effects of deregulation are stronger when new entrant banks are more prominent.
} 
forces shed new light on the mixed empirical evidence of previous studies and is also of crucial importance to policymakers.

Based on the estimated coefficients, we perform back-of-the-envelope calculations to quantify the magnitude of positive and negative effects of the 2009 deregulation policy. For the unintended credit distortion following deregulation, the coefficient of After2009.4×Exposure is 0.335 in column (2) of Table 3 . This suggests that the deregulation led to an annual 33.5\%increase in outstanding loans for SOEs within two years following the deregulation, and the total amount of SOE loans outstanding from joint equity banks was RMB 862 billion at the end of 2008. Thus, within two years following deregulation, the total amount of additional credit flows to SOEs is approximately RMB 674 billion $\left(862 \times\left((1+0.335)^{\wedge} 2-1\right)\right)$. This is equal to approximately $2.1 \%$ of China's GDP in 2008. We consider the RMB 674 billion SOE loans were lost since SOEs do not benefit from the deregulation, as shown in Table 8. The average ROA of private firms in 2008 was approximately $12.01 \%$. If we assume that the RMB 674 billion would be randomly allocated to private firms, the amount of loss on net profit is approximately RMB 80.9 billion, which is equal to $0.25 \%$ of GDP. Although the credit misallocation is short-run, the quite sizeable amount of money lent to SOEs in new markets was "lost".

For positive outcomes, the coefficient of After2009 $\times$ Exposure is 0.018 in column (8) of Table 7. This suggests that the deregulation led to a $1.8 \%$ increase in firms' ROA. Coupled with the total assets of the firms with bank loans in 2008 Census data of RMB 17.3 trillion, the deregulation led to RMB 311.4 billion increase in net profit (17.3×0.018), which is equal to approximately $0.97 \%$ of China's GDP in 2008.

Overall, on the one hand, the 2009 deregulation led to increases in growth in borrower's assets, employment, net income, and ROA. This accounts for $0.97 \%$ GDP gains. On the other hand, the 2009 deregulation led to more bank credit flows to SOEs that should have been granted to more productive private firms. This accounts for $0.25 \%$ GDP losses. These two opposing forces suggest that for policymakers, it is critical to fully understand all consequences of reforms, 
especially for interactions among different frictions. Lifting one friction can have unintended adverse effects arising from other frictions. The sequence is essential to reform success. In China, the soft budget constraints of SOEs can render credit allocation worse off after bank entry deregulation.

\section{Conclusion}

This paper examines the interbank competition dynamics and economic consequences following the deregulation on bank entry barriers in China. Using unique loan-level data and firm-level survey in China, we trace each loan issued by big five commercial banks and twelve joint equity banks. We find that after the 2009 bank entry deregulation, firms with bank credit access can benefit from increased competition among banks and receive better loan terms (e.g., lower interest rates). In contrast, deregulation leads to a worsening of credit allocation across firms, i.e., more bank credit flowing into SOEs, especially for inefficient ones with higher political rankings and softer budget constraints. These opposing forces shed new light on mixed evidence from previous studies on the economic consequences of banking deregulation.

Whether bank competition is good or bad for economic growth is a central question worldwide. This paper is the first to document specific competition dynamics occurring between new entrant banks and incumbent banks. We study not only the simple impacts between treated vs. control groups following deregulation but also the industrial organisation of the banking market, with spillovers depending on the local market and the identity types of banks and firms.

China has been experiencing unprecedented high rates of economic growth over recent decades and is now the second-largest economy worldwide. Throughout this period of economic growth, China has also developed the world's largest banking market. However, researchers, practitioners, and policymakers have heavily criticised inefficient modes of credit allocation in China. The Chinese government has been pushing financial reforms to improve this situation through, for instance, the banking sector deregulation. For policymakers, it is essential to understand the countervailing effects of banking deregulation and adverse effects in particular. 
Besides China, many other countries have various friction in financial markets, and it is critical to understand interactions occurring among such frictions. For example, other reforms should be implemented together with financial market reforms, e.g., removing government guarantees for SOEs as in this paper.

In future research, it is also essential to understand how the rapid change in China's banking sector has affected the global economy. What are the benefits and risks associated with the reform of banking systems in China? How do China's banking and shadow banking systems relate? Addressing these questions will further help us understand the world's largest bank debt market and its role in the global economy.

\section{References}

Ai, J., Bailey, W., Gao, H., Yang, X., and Zhao, L., 2016. Corporate default with Chinese characteristics. Unpublished working paper. Cornell University.

Allen, F., and Gale, D., 2000. Financial contagion. J ournal of Political Economy 108, 1-33.

Allen, F., Gersbach, H., Krahnen, J.P., and Santomero, A.M., 2001. Competition among banks: Introduction and conference overview. Review of Finance 5, 1-12.

Allen, F., Qian, J ., and Qian, M., 2005. Law, finance, and economic growth in China. J ournal of Financial Economics 77, 57-116.

Allen, F., Qian, J., and Qian, M., 2008. China's financial system: Past, present and future. Chapter 14 in China's Great Economic Transformation, edited by L. Brandt and T. Rawski, Cambridge University Press.

Allen, F., and Qian, J., 2014. China's financial system and the law. Cornell International Law J ournal 47, 499-553.

Barth, J.R., Caprio, G., and Levine, R., 2001. The regulation and supervision of banks around the world: A new database. Brookings-Wharton Papers on Financial Services, Brookings Institution Press, 183-240.

Barth, J.R., Caprio, G., and Levine, R., 2004. Bank regulation and supervision: What works best? J ournal of Financial Intermediation 13, 205-248.

Barth, J.R., Caprio, J.G., and Levine, R., 2013. Bank regulation and supervision in 180 countries from 1999 to 2011. J ournal of Financial Economic Policy 5, 111-219.

Berger, A.N., Demirgüç-Kunt, A., Levine, R., and Haubrich, J.G., 2004. Bank concentration and competition: An evolution in the making. J ournal of Money, Credit, and Banking 36, 433-451.

Berger, A.N., Demsetz, R., and Strahan, P., 1999. The consolidation of the financial services industry: Causes, consequences, and implications for the future. Journal of Banking and Finance 23, 135-194. 
Berger, A.N., Saunders, A., Scalise, J .M., and Udell, G.F., 1998. The effects of bank mergers and acquisitions on small business lending. J ournal of Financial Economics 50, 187-229.

Bertrand, M., Schoar, A., and Thesmar, D., 2007. Banking deregulation and industry structure: Evidence from the French banking reforms of 1985. J ournal of Finance 62, 597-628.

Black, S., and Strahan, P., 2002. Entrepreneurship and bank credit availability. J ournal of Finance 57, 2807-2833.

Boot, A.W., and Thakor, A.V., 2000. Can relationship banking survive competition? J ournal of Finance 55, 679-713.

Calvo, G., 1998. The simple economics of sudden stops. Journal of Applied Economics 1, 35-54.

Cetorelli, N., 2001. Does bank concentration lead to concentration in industrial sectors? Unpublished working paper. Federal Reserve Bank of New York.

Cetorelli, N., 2003. Life-cycle dynamics in industrial sectors: The role of banking market structure. Quarterly Review, Federal Reserve Bank of St. Louis 85, 135-147.

Cetorelli, N., and Gambera, M., 2001. Banking market structure, financial dependence and growth: International evidence from industry data. Journal of Finance 56, 617-648.

Cetorelli, N., and Strahan, P., 2006. Finance as a barrier to entry: Bank competition and industry structure in local U.S. markets. J ournal of Finance 61, 437-461.

Cetorelli, N., and Peretto, P., 2012. Credit quantity and credit quality: Bank competition and capital accumulation. J ournal of Economic Theory 147, 967-998.

Chen, H., Petukhov, A., and Wang, J., 2017. The dark side of circuit breakers. Unpublished working paper. MIT.

Chinn, M.D., and Ito, H., 2006. What matters for financial development? Capital controls, institutions, and interactions. J ournal of Development Economics 81, 163-192.

Claessens, S., Demirgüç-Kunt, A., and Huizinga, H., 2001. How does foreign entry affect domestic banking markets? J ournal of Banking and Finance 25, 891-911.

Cong, W.L., Gao, H., Ponticelli, J., and Yang, X., 2019. Credit allocation under economic stimulus: Evidence from China. Review of Financial Studies 32, 3412-3460.

Cull, R., and Xu, L.C., 2003. Who gets credit? The behavior of bureaucrats and state banks in allocating credit to Chinese state-owned enterprises. J ournal of Development Economics 71, 533-559.

Cull, R., and Xu, L.C., 2005. Institutions, ownership, and finance: The determinants of profit reinvestment among Chinese firms. J ournal of Financial Economics 77, 117-146.

Degryse, H., and Ongena, S., 2007. The impact of competition on bank orientation. J ournal of Financial Intermediation 16, 399-424.

Degryse, H., Laeven, L., and Ongena, S., 2009. The impact of organizational structure and lending technology on banking competition. Review of Finance 13, 225-259.

Demirgüç-Kunt, A., and Maksimovic, V., 1998. Law, finance, and firm growth. J ournal of Finance 53, 2107-2137.

Dell'Ariccia, G., and Marquez, R., 2004. Information and bank credit allocation. J ournal of Financial Economics 72, 185-214.

Dick, A., and Lehnert, A., 2010. Personal bankruptcy and credit market competition. J ournal of Finance 65, 655-686. 
Fischer, S., 1998. Capital account liberalization and the role of the IMF. Essays on International Finance No. 207, Department of Economics, Princeton University.

Goldsmith, R.W., 1969. Financial structure and development. Yale University Press.

Gormley, T.A., 2010. The impact of foreign bank entry in emerging markets: Evidence from India. J ournal of Financial Intermediation 19, 26-51

Gormley, T.A., 2014. Costly information, entry, and credit access. Journal of Economic Theory 154, 633-667

Gurley, J.G., and Shaw, E.S., 1955. Financial aspects of economic development. American Economic Review 45, 515-538.

Hachem, K., and Song, Z.M., 2016. Liquidity regulation and unintended financial transformation in China. Unpublished working paper. National Bureau of Economic Research.

Hachem, K., and Song, Z.M., 2017. Liquidity rules and credit booms. Unpublished working paper. University of Chicago.

Hakenes, H., and Schnabel, I., 2010. Credit risk transfer and bank competition. J ournal of Financial Intermediation 19, 308-332.

Hellmann, T.F., Murdock, K.C., and Stiglitz, J.E., 2000. Liberalization, moral hazard in banking, and prudential regulation: Are capital requirements enough? American Economic Review 90, 147-165.

Hsieh, C.T., and Klenow, P.J., 2009. Misallocation and manufacturing TFP in China and India. Quarterly J ournal of Economics 124, 1403-1448.

Hsieh, C.T., and Song, Z., 2015. Grasp the large, let go of the small: The transformation of the state sector in China. Brookings Papers on Economic Activity 3391, 295-366.

Huang, Y., Pagano, M., Panizza, U., 2017. Local crowding out in China. Unpublished working paper. Centre for Economic Policy Research.

J ayaratne, J ., and Strahan, P., 1996. The finance-growth nexus: Evidence from bank branch deregulation. Quarterly J ournal of Economics 111, 639-670.

Jayaratne, J., and Strahan, P., 1998. Entry restrictions, industry evolution, and dynamic efficiency: Evidence from commercial banking. J ournal of Law and Economics 41, 239-273.

Jiang, L., Levine, R., and Lin, C., 2016. Competition and bank opacity. Review of Financial Studies 29, 1911-1942.

Jiang, L., Levine, R., and Lin, C., 2017. Does competition affect bank risk? Unpublished working paper. National Bureau of Economic Research.

Jiang, L., Levine, R., and Lin, C., 2019. Competition and bank liquidity creation. J ournal of Financial and Quantitative Analysis 54, 513-538.

Kaminsky, G.L., and Schmukler, S.L., 2008. Short-run pain, long-run gain: Financial liberalization and stock market cycles. Review of Finance 12, 253-292.

Keeley, M.C., 1990. Deposit insurance, risk, and market power in banking. American Economic Review 80, 1183-1200.

King, R.G., and Levine, R., 1993a. Finance and growth: Schumpeter might be right. Quarterly J ournal of Economics 108, 717-737.

King, R.G., and Levine, R., 1993b. Finance, entrepreneurship and growth. J ournal of Monetary Economics 32, 513-542.

Levine, R., and Zervos, S., 1998. Stock markets, banks, and economic grouth. American Economic Review 88, 537-558. 
Levine, R., Loayza, N., and Beck, T., 2000. Financial intermediation and growth: Causality and causes. J ournal of Monetary Economics 46, 31-77.

$\mathrm{Liu}, \mathrm{Z}$., Wang P., and $\mathrm{Xu}, \mathrm{Z}$., 2017. Interest-rate liberalization and capital misallocation. Unpublished working paper. Federal Reserve Bank of San Francisco.

Lin, J.Y., and Tan, G., 1999. Policy burdens, accountability, and the soft budget constraint. American Economic Review 89, 426-431.

Marquez, R., 2002. Competition, adverse selection, and information dispersion in the banking industry. Review of Financial Studies 15, 901-926.

McKinnon, R.I., 1973. Money and capital in economic development. Brookings Institution Press.

Petersen, M.A., and Rajan, R.G., 1995. The effect of credit market competition on lending relationships. Quarterly J ournal of Economics 110, 407-443.

Petersen, M.A., and Rajan, R.G., 1994. The benefits of lending relationships: Evidence from small business data. J ournal of Finance 49, 3-37.

Prasad, E., Rogoff, K., Wei, S., and Kose, A., 2003. Effects of financial globalization on developing countries: Some empirical evidence. Occasional Paper No. 220, IMF.

Qian, Y., and Roland, G., 1998. Federalism and the soft budget constraint. American Economic Review 88, 1143-1162.

Rajan, R.G., and Zingales, L., 1998. Financial dependence and growth. American Economic Review 88, 559-586.

Smith, R., 1998. Banking competition and macroeconomic performance. J ournal of Money, Credit, and Banking 30, 793-815.

Song, Z., and Wu, G.L., 2015. Identifying capital misallocation. Unpublished working paper. Chinese University of Hong Kong.

Song, Z., and Xiong, W., 2018. Risks in China's financial system. Annual Review of Financial Economics 10, 261-286.

Wang, H., Wang, H., Wang, L., and Zhou, H., 2017. Shadow banking: China's dual-track interest rate liberalization. Unpublished working paper. Tsinghua University. 


\section{Table 1: Summary Statistics}

This table describes the summary statistics of the main variables used in this study. Panel A reports the city-bank-month sample from 2007 to 2013, Panel B reports the loan contract characteristics at loan level from J anuary 2007 to J une 2013, and Panel C reports the firm-level characteristics for merged China Industrial Census (CIC) data from 2004 to 2013. All variables are defined in Appendix Table A1.

\begin{tabular}{|c|c|c|c|c|c|c|}
\hline & $\mathrm{N}$ & Mean & Median & Std. Dev. & P1 & P99 \\
\hline & \multicolumn{6}{|c|}{ Panel A: City-Bank-Month Level } \\
\hline Outstanding Branches & 332,904 & 1.372 & 0.000 & 5.377 & 0.000 & 24.000 \\
\hline Outstanding Loans & 332,904 & 9.568 & 0.000 & 35.458 & 0.000 & 167.534 \\
\hline After2009.4 & 332,904 & 0.654 & 1.000 & 0.476 & 0.000 & 1.000 \\
\hline Exposure & 332,904 & 0.533 & 1.000 & 0.499 & 0.000 & 1.000 \\
\hline Local GDP (Billion RMB) & 332,904 & 145.044 & 82.504 & 197.413 & 48.155 & 1111.500 \\
\hline SOE-Share & 114,638 & 0.245 & 0.059 & 0.323 & 0.000 & 1.000 \\
\hline \multirow[t]{2}{*}{ High-TFP } & 114,638 & 0.507 & 0.477 & 0.354 & 0.000 & 1.000 \\
\hline & \multicolumn{6}{|c|}{ Panel B: Loan Characteristics } \\
\hline Loan Amount (Million RMB) & $1,863,445$ & 14.778 & 3.924 & 30.056 & 0.050 & 200.000 \\
\hline Maturity (in Months) & $1,863,445$ & 9.422 & 6.000 & 16.810 & 2.000 & 72.000 \\
\hline Rating Dummy & $1,863,445$ & 0.991 & 1.000 & 0.094 & 1.000 & 1.000 \\
\hline Guaranteed & $1,863,445$ & 0.241 & 0.000 & 0.428 & 0.000 & 1.000 \\
\hline Default & $1,508,679$ & 0.009 & 0.000 & 0.078 & 0.000 & 0.000 \\
\hline \multirow[t]{2}{*}{ Existing Borrower } & $1,863,445$ & 0.804 & 1.000 & 0.397 & 1.000 & 1.000 \\
\hline & \multicolumn{6}{|c|}{ Panel C: Firm Characteristics } \\
\hline$\overline{\text { Assets (Million RMB) }}$ & 343,071 & 415.862 & 198.665 & 512.657 & 5.350 & 1772.061 \\
\hline Fixed Assets (Million RMB) & 342,905 & 140.653 & 52.094 & 197.887 & 0.369 & 683.694 \\
\hline Leverage & 317,956 & 0.604 & 0.619 & 0.238 & 0.045 & 1.000 \\
\hline Sales (Million RMB) & 343,114 & 400.077 & 183.548 & 503.864 & 5.520 & 1755.216 \\
\hline Employee & 341,464 & 582.631 & 347.000 & 619.757 & 17.000 & 2271.000 \\
\hline Private & 343,117 & 0.935 & 1.000 & 0.247 & 0.000 & 1.000 \\
\hline Fixed Assets Growth & 293,321 & 0.599 & 0.021 & 2.502 & -0.966 & 2.888 \\
\hline Employee Growth & 292,739 & 0.261 & 0.028 & 0.949 & -0.850 & 1.514 \\
\hline Net Income Growth & 188,511 & 2.093 & 0.156 & 8.599 & -0.979 & 8.869 \\
\hline ROA & 342,354 & 0.061 & 0.030 & 0.112 & -0.143 & 0.634 \\
\hline $\mathrm{HHI}$ & 343,291 & 0.034 & 0.022 & 0.026 & 0.008 & 0.085 \\
\hline
\end{tabular}




\section{Table 2: J oint Equity Bank Expansions}

This table presents the results of the DID regressions of joint equity bank expansion at the citybank-month level. The dependent variables are Log(1+No. Branches) and Log(1+Outstanding Loans) in Panel A and B, respectively. The main independent variable is the interaction, After 2009.4×Exposure, where After2009.4 equals one for observations after the policy shock in April 2009 and zero before that. Exposure equals one when joint equity banks k in city j has outstanding branches in city j or the capital city of the province that the city j is located in before April 2009 (i.e., deregulated bank-city) and equals zero for big five banks in cities where no joint equity banks are allowed to freely expand after April 2009 and joint equity banks in these still regulated cities (i.e., unaffected bank-city). We exclude the bank's headquarter cities. For each panel, the column (1) reports the regression estimates for 3-month before and after the shock subsample (i.e., J anuary 2009 to J une 2009). The column (2), (3), and (4) report the regression estimates for 6-month, 12-month, 24-month before and after the shock subsample, respectively. Log(City GDP), Exposure, and After2009.4 are included in all model specifications. All variables are defined in Appendix Table A1. City-, Bank-, and Year-fixed effects are included across all models. Coefficients of the control variables, fixed effects dummies, and the constants are omitted for brevity. The t-statistics in parentheses are based on the two-way cluster-robust standard errors (cluster by city and bank) across all these model specifications. *, **, and *** indicate statistical significance at the $10 \%, 5 \%$, and $1 \%$ levels, respectively.

Panel A: Number of Branches

\begin{tabular}{c} 
Dependent Variable: Log (1+No. Branches) \\
\hline Shorter Window Longer Window
\end{tabular}

(1)

(2)

(3)

(4)

$[200901,200906] \quad[200810,200909] \quad[200804,201003] \quad[200704,201103]$

\begin{tabular}{lcccc}
\hline After2009.4×Exposure & $0.007^{* * *}$ & $0.017^{* * *}$ & $0.043^{* * * *}$ & $0.086^{* * * *}$ \\
& $(4.94)$ & $(8.59)$ & $(13.73)$ & $(17.13)$ \\
Controls & YES & YES & YES & YES \\
City FE & YES & YES & YES & YES \\
Bank FE & YES & YES & YES & YES \\
Year FE & YES & YES & YES & YES \\
Observations & 20,850 & 41,700 & 83,349 & 166,596 \\
Adjusted R-squared & 0.639 & 0.639 & 0.637 & 0.635 \\
\hline
\end{tabular}

Panel B: Outstanding Loan Amount

\begin{tabular}{|c|c|c|c|c|}
\hline & \multicolumn{4}{|c|}{ Dependent Variable: Log (1 + Outstanding Loan) } \\
\hline & \multicolumn{3}{|c|}{ Shorter Window } & \multirow{3}{*}{$\begin{array}{c}\text { Longer Window } \\
(4) \\
\text { 200704,201103 }\end{array}$} \\
\hline & (1) & (2) & (3) & \\
\hline & {$[200901,200906]$} & {$[200810,200909]$} & [200804,201003] & \\
\hline \multirow[t]{2}{*}{ After2009.4×Exposure } & $0.082^{* 2 k}$ & $0.144^{* * *}$ & $0.223^{* * k}$ & $0.312^{* * *}$ \\
\hline & (10.73) & (13.60) & (15.95) & (17.63) \\
\hline Controls & YES & YES & YES & YES \\
\hline City FE & YES & YES & YES & YES \\
\hline Bank FE & YES & YES & YES & YES \\
\hline Year FE & YES & YES & YES & YES \\
\hline Observations & 20,850 & 41,700 & 83,349 & 166,596 \\
\hline Adjusted R-squared & 0.695 & 0.695 & 0.693 & 0.688 \\
\hline
\end{tabular}




\section{Table 3: Deregulation and Credit Misallocation}

This table reports the results of the DID regressions of the bank loan allocation between SOEs and private firms. The dependent variables are SOE loans outstanding and the percentage of loans to SOEs at the city-bank-month level. Columns (1) and (4) report the regression estimates for 12-month before and after April 2009, columns (2) and (5) report the regression estimates for 24-month before and after April 2009, and columns (3) and (6) report the regression estimates for whole sample period from 2007 to 2013. The main independent variable is the interaction, After2009.4×Exposure, where After2009.4 equals one for observations after the policy shock in April 2009 and zero before that. Exposure equals one when joint equity banks k in city $\mathrm{j}$ has outstanding branches in city $\mathrm{j}$ or the capital city of the province that the city $\mathrm{j}$ is located in before April 2009 (i.e., deregulated bank-city) and equals zero for big five banks in cities where no joint equity banks are allowed to freely expand after April 2009 and joint equity banks in these still regulated cities (i.e., unaffected bank-city). We exclude the bank's headquarter cities. Pre-trend $d_{t-1}$, Pre-trend $\mathrm{t}_{\mathrm{t}-2}$, and Pre-trend $\mathrm{t}_{\mathrm{t}-3}$ are the interactions between Exposure and the time dummies indicating the 1-month, 2-month, and 3-month before April 2009, respectively. Exposure, After2009.4, and time dummies are included in all model specifications. City-, Bank-, and Year-fixed effects are included across all models. All variables are defined in Appendix Table A1. Coefficients of the control variables, fixed effects dummies, and the constants are omitted for brevity. The t-statistics in parentheses are based on the twoway cluster-robust standard errors (cluster by city and bank) across all these model specifications. ${ }^{*}, * *$, and ${ }^{* *}$ indicate statistical significance at the $10 \%, 5 \%$, and $1 \%$ levels, respectively.

\begin{tabular}{|c|c|c|c|c|c|c|}
\hline & \multicolumn{6}{|c|}{ Dependent Variable: Loans to SOE } \\
\hline & \multicolumn{3}{|c|}{ Log(Outstanding Loans) } & \multicolumn{3}{|c|}{ SOE-Share } \\
\hline & (1) & (2) & (3) & (4) & (5) & (6) \\
\hline & 1-Year & 2-Year & All & 1-Year & 2-Year & All \\
\hline \multirow[t]{2}{*}{ After2009.4×Exposure } & $0.393^{* *}$ & $0.335^{*}$ & 0.237 & $0.053 * *$ & $0.045^{*}$ & 0.024 \\
\hline & (2.43) & (1.73) & (1.26) & (2.56) & $(1.72)$ & $(0.88)$ \\
\hline \multirow[t]{2}{*}{ Pre-trendt-1 } & & 0.026 & -0.002 & & 0.013 & 0.013 \\
\hline & & $(0.14)$ & $(-0.01)$ & & $(0.52)$ & $(0.47)$ \\
\hline \multirow[t]{2}{*}{ Pre-trendt-2 } & & 0.153 & 0.086 & & 0.018 & 0.014 \\
\hline & & (1.09) & $(0.57)$ & & $(0.77)$ & $(0.55)$ \\
\hline \multirow[t]{2}{*}{ Pre-trendt-3 } & & 0.029 & -0.031 & & 0.004 & -0.000 \\
\hline & & $(0.23)$ & $(-0.22)$ & & $(0.20)$ & $(-0.02)$ \\
\hline Controls & Yes & Yes & Yes & Yes & Yes & Yes \\
\hline City FE & Yes & Yes & Yes & Yes & Yes & Yes \\
\hline Bank FE & Yes & Yes & Yes & Yes & Yes & Yes \\
\hline Year FE & Yes & Yes & Yes & Yes & Yes & Yes \\
\hline Observations & 27,356 & 57,353 & 115,229 & 27,349 & 57,342 & 115,216 \\
\hline Adjusted R-squared & 0.693 & 0.665 & 0.631 & 0.454 & 0.410 & 0.372 \\
\hline
\end{tabular}




\section{Table 4: Targeting Borrowers with Soft Budget Constraints}

This table reports the results of the DID regressions of the bank loan allocation efficiency. The dependent variables are the shares of outstanding loans to firms with higher TFP (i.e., High TFP Share) at the city-bank-month level. The main independent variable is the interaction, After2009.4×Exposure, where After2009.4 equals one for observations after the policy shock in April 2009 and zero before that. Exposure equals one when joint equity banks k in city j has outstanding branches in city j or the capital city of the province that the city j is located in before April 2009 (i.e., deregulated bank-city) and equals zero for big five banks in cities where no joint equity banks are allowed to freely expand after April 2009 and joint equity banks in these still regulated cities (i.e., unaffected bank-city). Columns (1) and (4) report the regression estimates for 12-month before and after April 2009, columns (2) and (5) report the regression estimates for 24-month before and after April 2009, and columns (3) and (6) report the regression estimates for whole sample period from 2007 to 2013. We exclude the bank's headquarter cities. Pre-trend $\mathrm{t}_{\mathrm{t}-1}$, Pre-trend $\mathrm{d}_{\mathrm{t}-2}$, and Pre-trend $\mathrm{d}_{\mathrm{t}-3}$ are the interactions between Exposure and the time dummies indicating the 1-month, 2-month, and 3-month before April 2009, respectively. Exposure, After2009.4, and time dummies are included in all model specifications. Coefficients of these control variables are omitted for brevity. All variables are defined in Appendix Table A1. City-, Bank-, and Year-fixed effects are included across all models. The t-statistics in parentheses are based on the two-way cluster-robust standard errors (cluster by city and bank) across all these model specifications. ${ }^{*}, * *$, and ${ }^{* * *}$ indicate statistical significance at the $10 \%, 5 \%$, and $1 \%$ levels, respectively.

\begin{tabular}{|c|c|c|c|c|c|c|}
\hline & \multicolumn{6}{|c|}{ Dependent Variable: High TFP Share } \\
\hline & \multicolumn{3}{|c|}{ For SOEs } & \multicolumn{3}{|c|}{ For Private Firms } \\
\hline & (1) & (2) & (3) & (4) & (5) & (6) \\
\hline & 1-Year & 2-Year & All & 1-Year & 2-Year & All \\
\hline \multirow[t]{2}{*}{ After2009.4×Exposure } & $-0.047^{* *}$ & $-0.063^{* *}$ & -0.054 & -0.019 & -0.018 & -0.012 \\
\hline & $(-2.15)$ & $(-2.11)$ & $(-1.55)$ & $(-0.76)$ & $(-0.56)$ & $(-0.36)$ \\
\hline \multirow[t]{2}{*}{ Pre-trendt-1 } & & -0.039 & -0.042 & & -0.028 & -0.022 \\
\hline & & $(-1.51)$ & $(-1.51)$ & & $(-1.00)$ & $(-0.79)$ \\
\hline \multirow{2}{*}{ Pre-trendt-2 } & & -0.013 & -0.010 & & -0.028 & -0.027 \\
\hline & & $(-0.64)$ & $(-0.45)$ & & $(-1.17)$ & $(-1.02)$ \\
\hline \multirow[t]{2}{*}{ Pre-trendt-3 } & & -0.026 & -0.023 & & -0.030 & -0.027 \\
\hline & & $(-1.30)$ & $(-0.99)$ & & $(-1.25)$ & $(-1.04)$ \\
\hline Controls & Yes & Yes & Yes & Yes & Yes & Yes \\
\hline City FE & Yes & Yes & Yes & Yes & Yes & Yes \\
\hline Bank FE & Yes & Yes & Yes & Yes & Yes & Yes \\
\hline Year FE & Yes & Yes & Yes & Yes & Yes & Yes \\
\hline Observations & 15,259 & 32,093 & 60,578 & 24,991 & 52,748 & 105,120 \\
\hline Adjusted R-squared & 0.558 & 0.518 & 0.455 & 0.433 & 0.385 & 0.325 \\
\hline
\end{tabular}


Table 5: Dynamic of Information Disadvantage for New Entrant Bank Branches

This table reports the descriptive statistics (mean value) of the bank's early downgrade warning on delinquent borrowers. Conditional on delinquent loans, the Early Downgrade Dummy is the dummy variable that equals one if the delinquent loan's internal rating is downgraded by the bank before the delinquency and zero otherwise. Early Downgrade Months measures the months between the date of the first downgrade and the delinquent date. For each delinquent loan from bank $\mathrm{k}$ in city $\mathrm{j}$, Panel A first calculate the months between the month of bank k starting to open a branch in city $\mathrm{j}$ and the loan issuance month and then group the delinquent loans into three groups based on the time lag (i.e., <2Years, 2 3Years, and >3Years, respectively). Panel B calculate the months between the month of bank $\mathrm{k}$ starting to open a branch in city $\mathrm{j}$ and the loan due month and similarly group the delinquent loans into three groups.

\begin{tabular}{|c|c|c|c|c|}
\hline & \multirow[b]{3}{*}{$\mathrm{N}$} & \multicolumn{3}{|c|}{ Panel A: based on loan issuance month } \\
\hline & & Early Downgrade Dummy & \multirow[b]{2}{*}{$\mathrm{N}$} & Early Downgrade Months \\
\hline & & (1) & & (2) \\
\hline$<2$ Years & 106 & $22.64 \%$ & 24 & 4.63 \\
\hline 2-3Years & 212 & $25.47 \%$ & 54 & 5.04 \\
\hline \multirow[t]{4}{*}{$>3$ Years } & 18,480 & $42.31 \%$ & 7,819 & 5.39 \\
\hline & & \multicolumn{3}{|c|}{ Panel B: based on loan due month } \\
\hline & & Early Downgrade Dummy & & Early Downgrade Months \\
\hline & $\mathrm{N}$ & (1) & $\mathrm{N}$ & (2) \\
\hline$<2$ Years & 90 & $13.33 \%$ & 12 & 4.08 \\
\hline 2-3Years & 205 & $18.53 \%$ & 38 & 2.72 \\
\hline$>3$ Years & 18,532 & $42.39 \%$ & 7,856 & 5.40 \\
\hline
\end{tabular}


Table 6: The Impacts of Deregulation on Loan Contract Terms and Performance This table reports the results of the DID regression estimates of loan contract terms. The dependent variables are loan-level Rating, Guaranteed, and Default, respectively. The main independent variable is the interaction, After2009.4×Exposure, where After2009.4 equals one for observations after the policy shock in April 2009 and zero before that. Exposure equals one when joint equity banks k in city $\mathrm{j}$ has outstanding branches in city $\mathrm{j}$ or the capital city of the province that the city $\mathrm{j}$ is located in before April 2009 (i.e., deregulated bank-city) and equals zero for big five banks in cities where no joint equity banks are allowed to freely expand after April 2009 and joint equity banks in these still regulated cities (i.e., unaffected bank-city). We exclude the bank's headquarter cities. Pretrend_1, Pretrend_2, and Pretrend 3 are the interactions between Exposure and the time dummies indicating the 1-month, 2month, and 3-month before April 2009, respectively. Log(Assets), Leverage, Exposure, and After2009.4 are included in all model specifications. Coefficients of these control variables are omitted for brevity. All variables are defined in Appendix Table A1. Firm-, Bank-, and Year-fixed effects are included across all models. The t-statistics in parentheses are based on the cluster-robust standard errors at the firm level in all columns. ${ }^{*},{ }^{* *}$, and ${ }^{* * *}$ indicate statistical significance at the $10 \%, 5 \%$, and $1 \%$ levels, respectively.

\begin{tabular}{|c|c|c|c|c|c|c|}
\hline & \multicolumn{3}{|c|}{ Private Firms } & \multicolumn{3}{|c|}{ SOEs } \\
\hline & (1) & (2) & (3) & (4) & (5) & (6) \\
\hline & Rating & Guaranteed & Default & Rating & Guaranteed & Default \\
\hline After2009.4×Exposure & $\begin{array}{l}0.008^{\text {*k* }} \\
(4.16)\end{array}$ & $\begin{array}{l}0.017^{* * *} \\
(4.15)\end{array}$ & $\begin{array}{c}-0.005^{*} \\
(-1.94)\end{array}$ & $\begin{array}{l}0.005 \\
(1.36)\end{array}$ & $\begin{array}{l}0.002 \\
(0.19)\end{array}$ & $\begin{array}{c}0.002 \\
(0.77)\end{array}$ \\
\hline Controls & Yes & Yes & Yes & Yes & Yes & Yes \\
\hline Firm FE & Yes & Yes & Yes & Yes & Yes & Yes \\
\hline Bank FE & Yes & Yes & Yes & Yes & Yes & Yes \\
\hline Year FE & Yes & Yes & Yes & Yes & Yes & Yes \\
\hline Observations & 872,852 & 872,852 & 854,510 & 129,049 & 129,049 & 120,265 \\
\hline Adjusted R-squared & 0.218 & 0.488 & 0.310 & 0.199 & 0.482 & 0.197 \\
\hline
\end{tabular}




\section{Table 7: The Impacts of Deregulation on Firms}

This table reports the results of the DID regressions of firm activities and performance. We merge the CIC firm-level data with the $\backslash$ loan data and restrict the sample to the firms which have ever borrowed bank loans between 2006 and 2013. The dependent variable in columns (1) and (2) is the growth of fixed assets. Columns (3) and (4) are for employee grouth. Columns (5) and (6) are for net income growth. Columns (7) and (8) are for ROA (Return on Assets). Regression results over the 6-year window and 10-year window are reported. Our main independent variable is After2009 ×Exposure, where After2009 equals one for observations after the year of 2009 and zero before and Exposure equals one for treated cities (at least one joint equity bank can open branches freely in that city after the deregulation, i.e., either the city or its capital city has outstanding joint-equity branches prior to the bank expansion policy shock) and zero for controlled cities. Pre-trendt-1 and Pre-trendt-2 are for parallel pre-trends, where Pre-trendt-1 equals year dummy for 2008 times Exposure, and Pre-trendt-2 equals year dummy for 2007 times Exposure. Exposure, After2009, and time dummies are included in all model specifications. Coefficients of these control variables are omitted for brevity. All regressions are controlled for firm fixed effect and year fixed effect. Standard errors are clustered at the firm level, and thet-statistics are reported in parentheses across all these model specifications. ${ }^{*},{ }^{* *}$, and ${ }^{* * *}$ indicate statistical significance at the $10 \%, 5 \%$, and $1 \%$ levels, respectively.

\begin{tabular}{|c|c|c|c|c|c|c|c|c|}
\hline & (1) & (2) & (3) & (4) & (5) & (6) & (7) & (8) \\
\hline & \multicolumn{2}{|c|}{ Fixed Assets Growth } & \multicolumn{2}{|c|}{ Employee Growth } & \multicolumn{2}{|c|}{ Net Income Growth } & \multicolumn{2}{|c|}{$\mathrm{ROA}$} \\
\hline & {$[2006,2011]$} & {$[2004,2013]$} & {$[2006,2011]$} & {$[2004,2013]$} & {$[2006,2011]$} & {$[2004,2013]$} & {$[2006,2011]$} & {$[2004,2013]$} \\
\hline After2009×Exposure & $\begin{array}{l}0.341^{* * *} \\
(6.42)\end{array}$ & $\begin{array}{l}0.213^{\text {*atk }} \\
(5.65)\end{array}$ & $\begin{array}{l}0.148^{\text {*a* }} \\
(5.40)\end{array}$ & $\begin{array}{l}0.081^{* * * *} \\
(4.43)\end{array}$ & $\begin{array}{l}0.872^{\text {*k* }} \\
(4.27)\end{array}$ & $\begin{array}{l}0.440^{* * * *} \\
(3.48)\end{array}$ & $\begin{array}{l}0.019^{\text {**** }} \\
(6.45)\end{array}$ & $\begin{array}{c}0.018^{* * * *} \\
(7.24)\end{array}$ \\
\hline Pre-trend $d_{t-1}$ & $\begin{array}{l}-0.080 \\
(-1.48)\end{array}$ & $\begin{array}{l}-0.071 \\
(-1.58)\end{array}$ & $\begin{array}{l}0.027 \\
(1.03)\end{array}$ & $\begin{array}{c}0.007 \\
(0.31)\end{array}$ & $\begin{array}{l}-0.098 \\
(-0.54)\end{array}$ & $\begin{array}{l}-0.073 \\
(-0.48)\end{array}$ & $\begin{array}{l}-0.004 \\
(-1.10)\end{array}$ & $\begin{array}{l}-0.005 \\
(-1.43)\end{array}$ \\
\hline Pre-trend $t-2$ & $\begin{array}{c}0.005 \\
(0.10)\end{array}$ & $\begin{array}{c}0.015 \\
(0.37)\end{array}$ & $\begin{array}{c}0.039 \\
(1.43)\end{array}$ & $\begin{array}{r}0.018 \\
(0.80)\end{array}$ & $\begin{array}{l}-0.292 \\
(-1.52)\end{array}$ & $\begin{array}{l}-0.256 \\
(-1.53)\end{array}$ & $\begin{array}{l}-0.004 \\
(-1.26)\end{array}$ & $\begin{array}{c}-0.006^{*} \\
(-1.75)\end{array}$ \\
\hline Controls & Yes & Yes & Yes & Yes & Yes & Yes & Yes & Yes \\
\hline Firm FE & Yes & Yes & Yes & Yes & Yes & Yes & Yes & Yes \\
\hline Year FE & Yes & Yes & Yes & Yes & Yes & Yes & Yes & Yes \\
\hline Observations & 174,275 & 293,125 & 173,104 & 292,545 & 96,386 & 188,434 & 205,658 & 342,096 \\
\hline Adjusted R-squared & 0.053 & 0.050 & 0.058 & 0.051 & 0.006 & 0.008 & 0.019 & 0.015 \\
\hline
\end{tabular}

Table 8: The Impacts of Deregulation on SOEs vs. Private Firms 
This table reports the results of the DID regressions of activities and performance for SOEs and private firms. We merge the CIC firmlevel data with the loan data and restrict the sample to the firms which have ever borrowed bank loans between 2006 and 2013 . The dependent variable in columns (1) and (2) is the growth of fixed assets. Columns (3) and (4) are for employee growth. Columns (5) and (6) are for net income growth. Columns (7) and (8) are for ROA (Return on Assets). Regression results over the 6-year window and 10-year window are reported. Our main independent variable is After2009×Exposure, where After2009 equals one for observations after the year of 2009 and zero before and Exposure equals one for treated cities (at least one joint equity bank can open branches freely in that city after the deregulation, i.e., either the city or its capital city has outstandingJ oint-equity branches prior to the bank expansion policy shock) and zero for controlled cities. Private equals one if the firm is private-owned and zero otherwise. Pre-trendt-1 and Pre-trendt-2 are for parallel pre-trends, where Pre-trendt-1 equals year dummy for 2008 times Exposure, and PreTrendt-2 equals year dummy for 2007 times Exposure. Exposure, After2009, and time dummies are included in all model specifications. Coefficients of these control variables are omitted for brevity. All regressions are controlled for firm fixed effect and year fixed effect. Standard errors are clustered at the firm level, and the t-statistics are reported in parentheses across all these model specifications. * ${ }^{* *}$, and ${ }^{* * *}$ indicate statistical significance at the $10 \%, 5 \%$, and $1 \%$ levels, respectively.

\begin{tabular}{|c|c|c|c|c|c|c|c|c|}
\hline & (1) & (2) & (3) & (4) & (5) & (6) & (7) & (8) \\
\hline & \multicolumn{2}{|c|}{ Fixed Assets Growth } & \multicolumn{2}{|c|}{ Employee Growth } & \multicolumn{2}{|c|}{ Net Income Growth } & \multicolumn{2}{|c|}{ ROA } \\
\hline & {$[2006,2011]$} & {$[2004,2013]$} & {$[2006,2011]$} & {$[2004,2013]$} & {$[2006,2011]$} & {$[2004,2013]$} & {$[2006,2011]$} & {$[2004,2013]$} \\
\hline After2009×Exposure×Private & $\begin{array}{l}0.505^{* * *} \\
(4.31)\end{array}$ & $\begin{array}{l}0.336^{* * *} \\
(4.05)\end{array}$ & $\begin{array}{l}0.160^{* * *} \\
(2.71)\end{array}$ & $\begin{array}{l}0.112^{* * *} \\
(2.91)\end{array}$ & $\begin{array}{l}1.099^{* *} \\
(2.22)\end{array}$ & $\begin{array}{l}0.918^{* * *} \\
(2.85)\end{array}$ & $\begin{array}{l}0.026^{* * *} \\
(4.39)\end{array}$ & $\begin{array}{l}0.026^{* * *} \\
(5.02)\end{array}$ \\
\hline After2009×Exposure & $\begin{array}{l}-0.167 \\
(-1.56)\end{array}$ & $\begin{array}{l}-0.117 \\
(-1.58)\end{array}$ & $\begin{array}{c}0.020 \\
(0.36)\end{array}$ & $\begin{array}{c}0.002 \\
(0.05)\end{array}$ & $\begin{array}{l}-0.209 \\
(-0.45)\end{array}$ & $\begin{array}{l}-0.435 \\
(-1.45)\end{array}$ & $\begin{array}{l}-0.004 \\
(-0.65)\end{array}$ & $\begin{array}{l}-0.003 \\
(-0.96)\end{array}$ \\
\hline Pre-trend $d_{t-1}$ & $\begin{array}{l}-0.084 \\
(-1.57)\end{array}$ & $\begin{array}{l}-0.072 \\
(-1.61)\end{array}$ & $\begin{array}{c}0.014 \\
(0.62)\end{array}$ & $\begin{array}{c}0.000 \\
(0.00)\end{array}$ & $\begin{array}{l}-0.109 \\
(-0.61)\end{array}$ & $\begin{array}{l}-0.072 \\
(-0.48)\end{array}$ & $\begin{array}{l}-0.004 \\
(-1.07)\end{array}$ & $\begin{array}{l}-0.005 \\
(-1.41)\end{array}$ \\
\hline Pre-trend $\mathrm{t}_{-2}$ & $\begin{array}{l}-0.007 \\
(-0.14)\end{array}$ & $\begin{array}{l}0.005 \\
(0.13)\end{array}$ & $\begin{array}{l}0.033 \\
(1.41)\end{array}$ & $\begin{array}{c}0.016 \\
(0.83)\end{array}$ & $\begin{array}{l}-0.288 \\
(-1.51)\end{array}$ & $\begin{array}{l}-0.254 \\
(-1.53)\end{array}$ & $\begin{array}{l}-0.004 \\
(-1.24)\end{array}$ & $\begin{array}{l}-0.006^{*} \\
(-1.78)\end{array}$ \\
\hline Controls & Yes & Yes & Yes & Yes & Yes & Yes & Yes & Yes \\
\hline Firm FE & Yes & Yes & Yes & Yes & Yes & Yes & Yes & Yes \\
\hline Year FE & Yes & Yes & Yes & Yes & Yes & Yes & Yes & Yes \\
\hline Observations & 174,067 & 292,764 & 172,894 & 292,180 & 96,249 & 188,185 & 205,400 & 341,654 \\
\hline Adjusted R-squared & 0.055 & 0.051 & 0.060 & 0.053 & 0.006 & 0.008 & 0.020 & 0.015 \\
\hline
\end{tabular}


Table 9: The Impacts of Deregulation on Firms across Cities

This table reports the results of the DID regressions of firm activities and performance. We merge the CIC firm-level data with the CBRC loan data and restrict the sample to the firms which have ever borrowed bank loans between 2006 and 2013. The dependent variable in columns (1) and (2) is the growth of fixed assets. Columns (3) and (4) are for employee growth. Columns (5) and (6) are for net income growth. Columns (7) and (8) are for ROA (Return on Assets). Regression results over the 6-year window and 10-year window are reported. Our main independent variable is After2009×Exposure, where After2009 equals one for observations after the year of 2009 and zero before and Exposure equals one for treated cities (at least one joint equity bank can open branches freely in that city after the deregulation, i.e., either the city or its capital city has outstanding J oint-equity branches prior to the bank expansion policy shock) and zero for controlled cities. HHI is the Herfindahl-Hirschman Index of outstanding branch number before the shock for each city. Pre-trendt-1 and Pre-trendt-2 are for parallel pre-trends, where Pre-trendt-1 equals year dummy for 2008 times Exposure, and Pre-trendt-2 equals year dummy for 2007 times Exposure. Exposure, After2009, HHI, and time dummies are included in all model specifications. Coefficients of these control variables are omitted for brevity. All regressions are controlled for firm fixed effect and year fixed effect. Standard errors are clustered at the firm level, and the t-statistics are reported in parentheses across all these model specifications. $*$, **, and *** indicate statistical significance at the $10 \%, 5 \%$, and $1 \%$ levels, respectively.

\begin{tabular}{|c|c|c|c|c|c|c|c|c|}
\hline & (1) & (2) & (3) & (4) & (5) & (6) & (7) & (8) \\
\hline & \multirow{2}{*}{\multicolumn{2}{|c|}{$\begin{array}{l}\text { Fixed Assets Growth } \\
{[2006,2011][2004,2013]}\end{array}$}} & \multicolumn{2}{|c|}{ Employee Growth } & \multicolumn{2}{|c|}{ Net Income Growth } & \multicolumn{2}{|c|}{ ROA } \\
\hline & & & {$[2006,2011]$} & {$[2004,2013]$} & [2006, 2011] & {$[2004,2013]$} & {$[2006,2011]$} & {$[2004,2013]$} \\
\hline After2009×Exposure×HHI & $\begin{array}{l}1.542^{*} \\
(1.94)\end{array}$ & $\begin{array}{l}{ }^{1.962^{* * * *}} \\
(3.12)\end{array}$ & $\begin{array}{l}0.642 \\
(1.38)\end{array}$ & $\begin{array}{l}0.522^{* *} \\
(2.35)\end{array}$ & $\begin{array}{l}4.270 \\
(1.55)\end{array}$ & $\begin{array}{c}0.695 \\
(0.29)\end{array}$ & $\begin{array}{l}0.226^{\text {**** }} \\
(6.07)\end{array}$ & $\begin{array}{l}0.246^{* * *} \\
(5.38)\end{array}$ \\
\hline After2009×Exposure & $\begin{array}{l}0.247^{\text {tow }} \\
(3.43)\end{array}$ & $\begin{array}{l}0.108^{*} \\
(1.91)\end{array}$ & $\begin{array}{l}0.110^{* * *} \\
(2.77)\end{array}$ & $\begin{array}{l}0.055^{* *} \\
(2.44)\end{array}$ & $\begin{array}{l}0.522^{*} \\
(1.93)\end{array}$ & $\begin{array}{l}0.237 \\
(1.13)\end{array}$ & $\begin{array}{l}0.015^{\text {*** }} \\
(3.43)\end{array}$ & $\begin{array}{l}0.014^{* * *} \\
(3.04)\end{array}$ \\
\hline Pre-trend $d_{t-1}$ & $\begin{array}{l}-0.078 \\
(-1.62)\end{array}$ & $\begin{array}{l}-0.070 \\
(-1.64)\end{array}$ & $\begin{array}{r}0.110 \\
(0.43)\end{array}$ & $\begin{array}{l}0.203 \\
(0.95)\end{array}$ & $\begin{array}{l}-1.726^{* *} \\
(-2.46)\end{array}$ & $\begin{array}{l}-1.108^{*} \\
(-1.71)\end{array}$ & $\begin{array}{l}-0.017 \\
(-0.99)\end{array}$ & $\begin{array}{c}-0.004 \\
(-0.24)\end{array}$ \\
\hline Pre-trend $\mathrm{t}-2_{2}$ & $\begin{array}{l}0.005 \\
(0.10)\end{array}$ & $\begin{array}{c}0.014 \\
(0.36)\end{array}$ & $\begin{array}{l}0.029 \\
(1.02)\end{array}$ & $\begin{array}{l}0.008 \\
(0.36)\end{array}$ & $\begin{array}{c}-0.087 \\
(-0.44)\end{array}$ & $\begin{array}{c}-0.060 \\
(-0.36)\end{array}$ & $\begin{array}{l}-0.004 \\
(-0.96)\end{array}$ & $\begin{array}{l}-0.005 \\
(-1.23)\end{array}$ \\
\hline Controls & Yes & Yes & Yes & Yes & Yes & Yes & Yes & Yes \\
\hline Firm FE & Yes & Yes & Yes & Yes & Yes & Yes & Yes & Yes \\
\hline Year FE & Yes & Yes & Yes & Yes & Yes & Yes & Yes & Yes \\
\hline Observations & 174,067 & 292,764 & 172,894 & 292,180 & 96,249 & 188,185 & 205,400 & 341,654 \\
\hline Adjusted R-squared & 0.246 & 0.210 & 0.232 & 0.190 & 0.304 & 0.268 & 0.548 & 0.522 \\
\hline
\end{tabular}


Internet Appendix for "Rise of Bank Competition: Evidence from Banking Deregulation in China" 


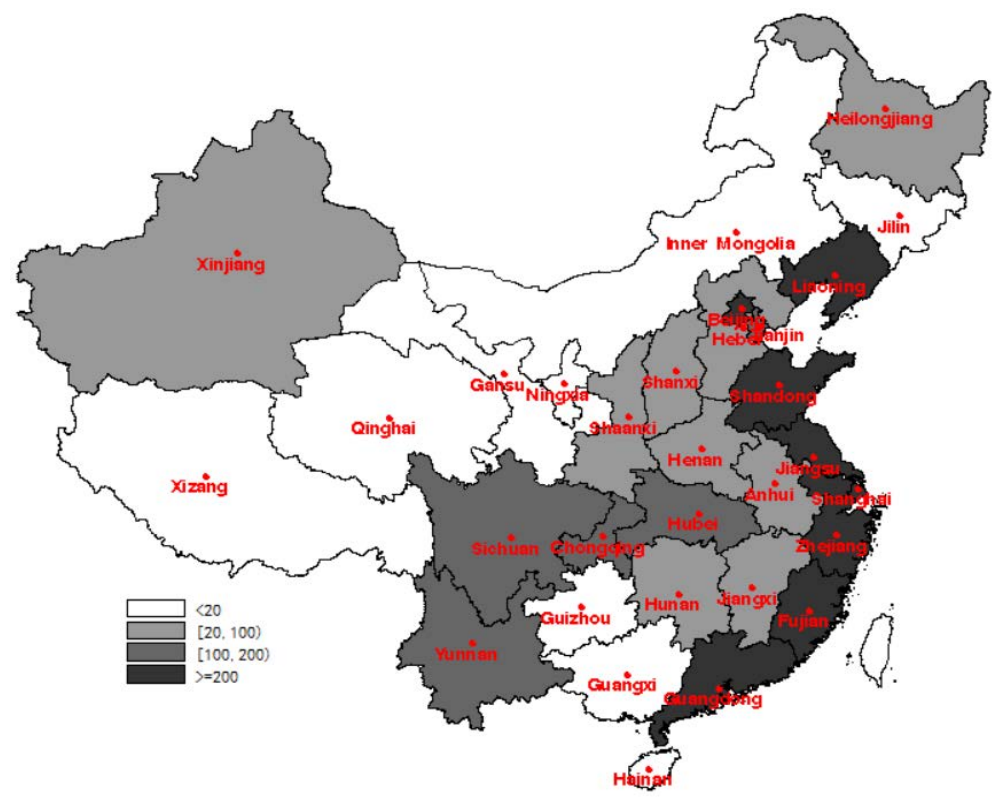

Panel A: By the Year 2008

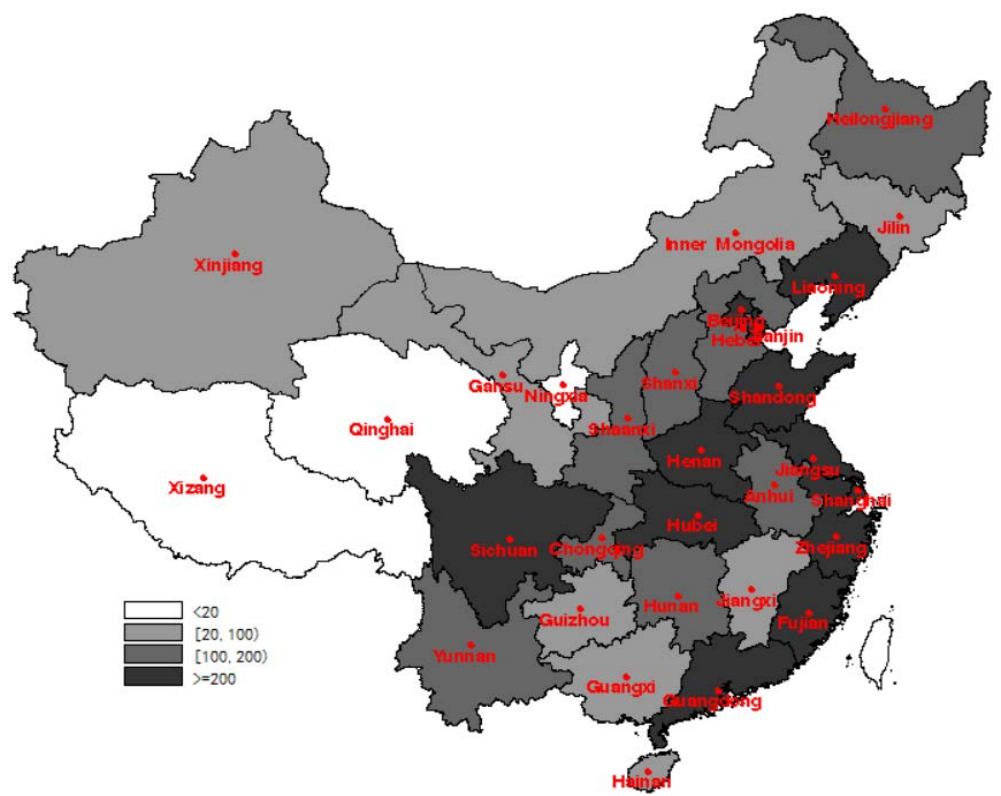

Panel B: By the Year 2013

Figure A1: Heat Map of the Number of J oint-equity Branches across Provinces, 2008 versus 2013. This figure illustrates the number of all twelve joint-equity branches outstanding across all provinces in China at the end of 2008 (Panel A) and 2013 (Panel B). It covers 31 provinces, including four centrally administrated cities (i.e., Shanghai, Beijing, Tianjin, and Chongqing). 


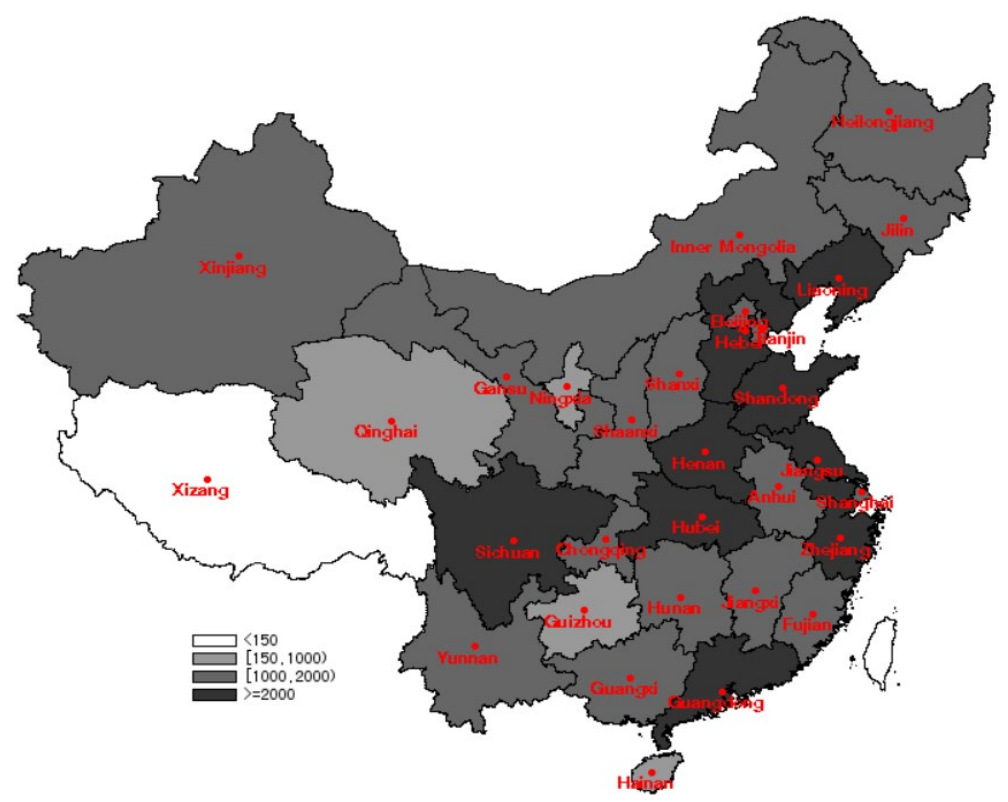

Panel A: By the Year 2008

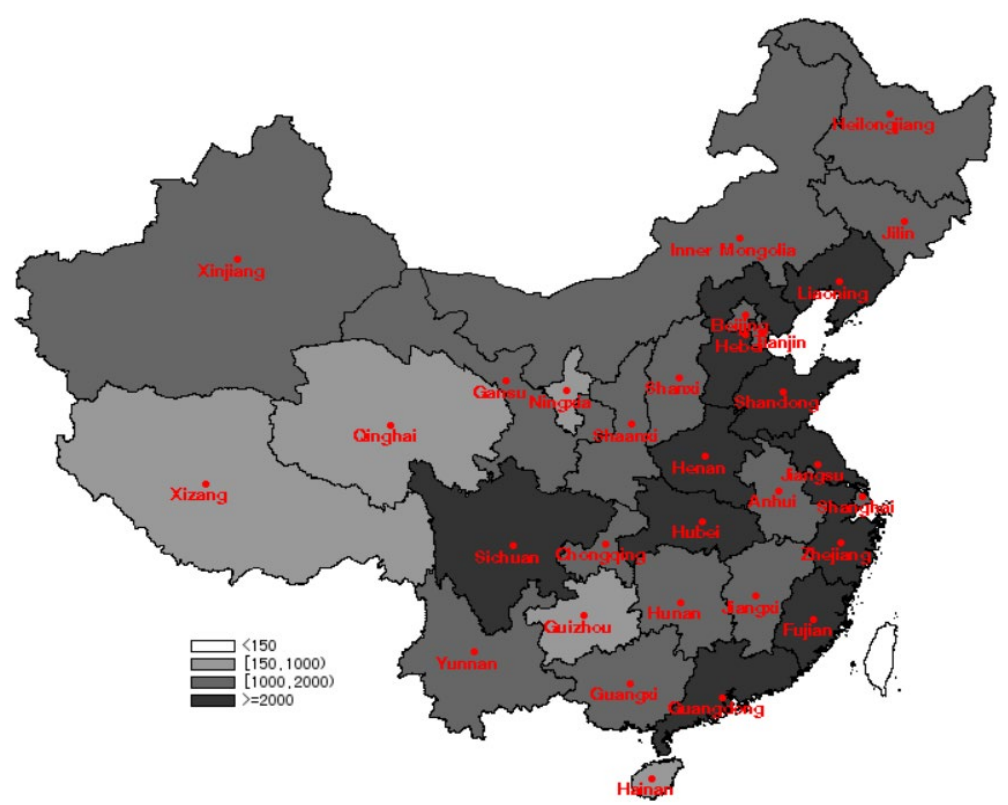

Panel B: By the Year 2013

Figure A2: Heat Map of the Number of Big Five Banks' Branches across Provinces, 2008 vs. 2013. This figure illustrates the number of big five bank branches outstanding for all provinces in China at the end of 2008 (Panel A) and 2013 (Panel B). It covers 31 provinces, including four centrally administrated cities (i.e., Shanghai, Beijing, Tianjin, and Chongqing). 


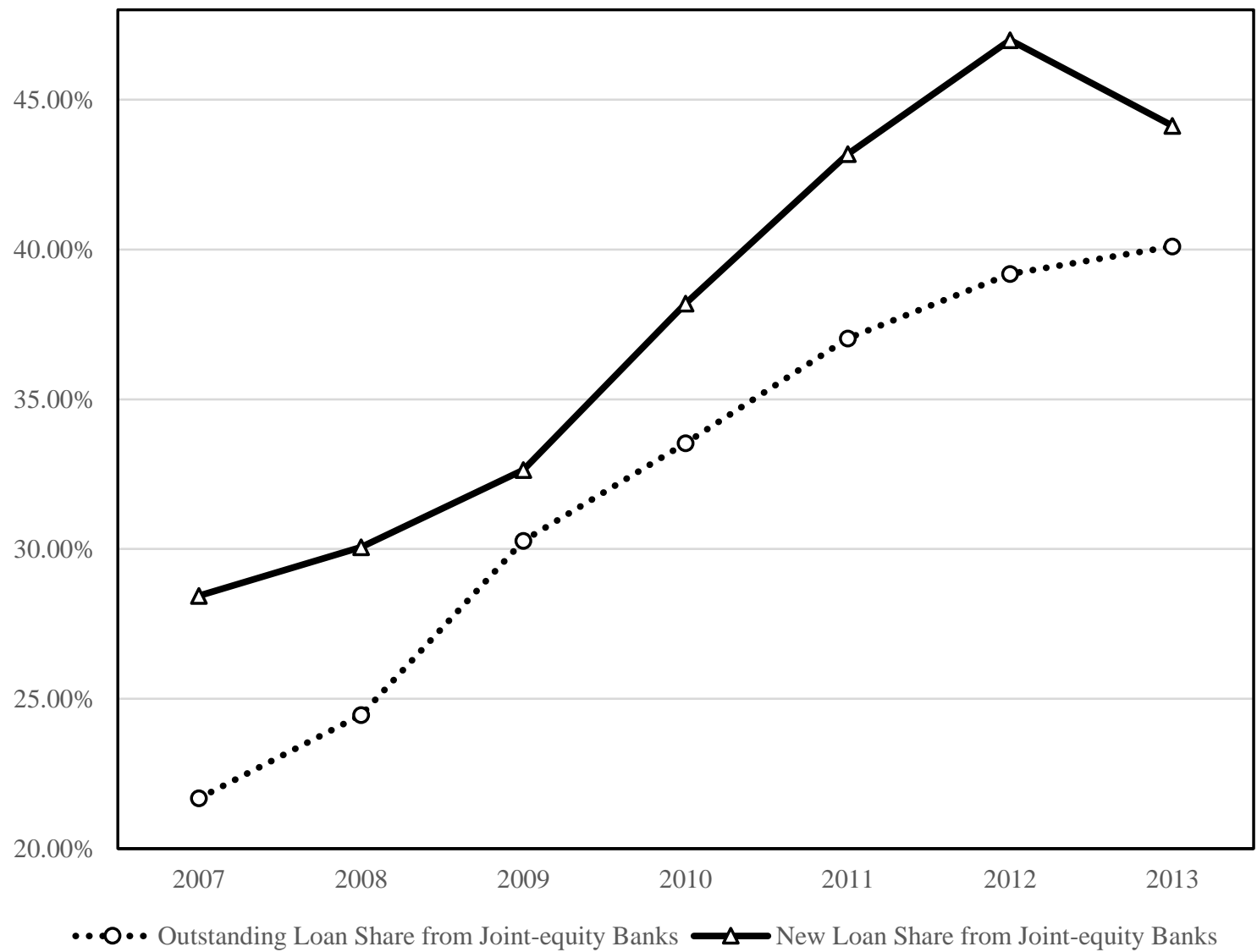

Figure A3: Expansion of J oint-equity Banks. This figure plots the annual share of joint-equity banks from 2007 to 2013 . The dotted line with circles exhibits the joint equity banks' share of loans outstanding, and the solid line with triangles exhibits the share of new loan issuances. The share is calculated by the amount of loans granted by joint-equity banks over the total amount of loans granted by both joint-equity banks and big five commercial banks. 


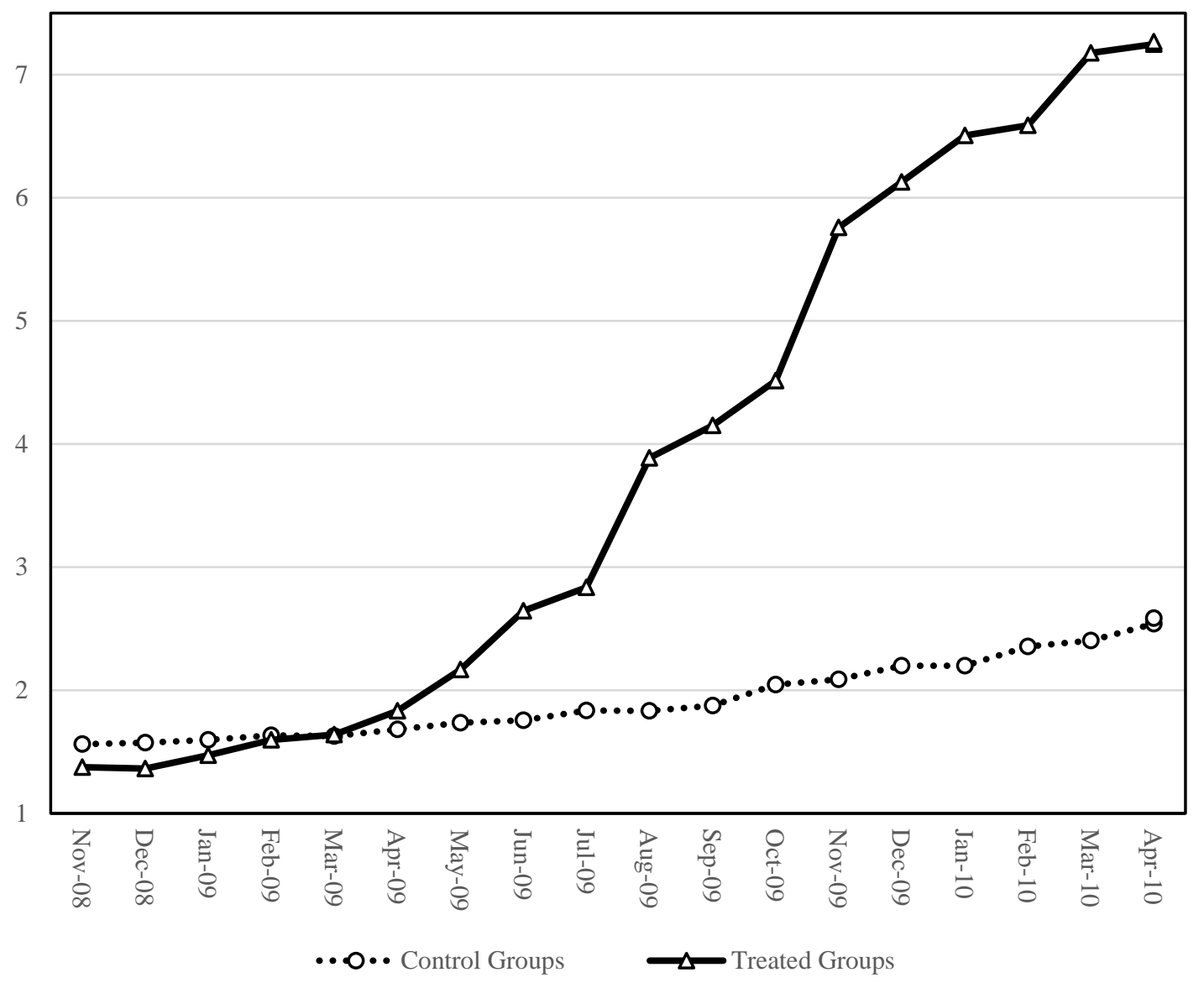

Figure A4: Time Trends of Loans Outstanding: treatment vs. control groups. This figure plots the amounts of loans outstanding between treatment and control groups at the bank-cities level before and after the April 2009 bank entry deregulation. The solid line with triangles exhibits the amount of joint equity bank loans outstanding in their deregulated cities (e.g., joint-equity bank $\mathrm{k}$ is treated in city $\mathrm{j}$ if bank $\mathrm{k}$ has branches in city j or its capital city of the province before April 2009). The dotted line with circles represents big five banks that are in still regulated cities (i.e., control group). The vertical axis reports the demeaned amount of natural logarithm of loans outstanding. 
Table A1: Variable Definition

\begin{tabular}{|c|c|}
\hline & \\
\hline Variables & Definitions \\
\hline After2009.4 & A dummy variable that equals one if it is after the deregulation shock and zero otherwise. \\
\hline Exposure & $\begin{array}{l}\text { A dummy variable at the city-bank level that equals one if the joint-equity bank has outstanding branches in this city } \\
\text { or its capital city of the province before the bank expansion policy shock and zero otherwise. }\end{array}$ \\
\hline Loan Amount & The balance of each loan contract. The unit is in a million RMB. \\
\hline Maturity & The term of each loan contract. The unit is in years. \\
\hline Rating Dummy & $\begin{array}{l}\text { The credit score placed by the loan officers in the bank. The larger the number, the worse the credit quality of the } \\
\text { borrower. It takes the value of one if the rating is at the first category and zero otherwise. }\end{array}$ \\
\hline Guaranteed & A dummy variable that equals one if the bank requires third-party guarantee protections and zero otherwise. \\
\hline Existing Borrower & $\begin{array}{l}\text { A dummy variable that equals one if the bank had a lending relationship with the firm during the prior } 12 \text { months } \\
\text { and zero otherwise. }\end{array}$ \\
\hline Delinquent & A loan performance measure that equals one if the loan is not repaid on time and zero otherwise. \\
\hline Default & $\begin{array}{l}\text { A loan performance measure that equals one if the loan is not repaid over three months after the due date and zero } \\
\text { otherwise. }\end{array}$ \\
\hline ATR & Asset turnover ratio is defined as the total operating income divided by total assets. \\
\hline Higher ATR & $\begin{array}{l}\text { A dummy indicates whether the assets turnover ratio is above the median value of the firms' assets turnover ratio in } \\
\text { census } 2008 \text {. }\end{array}$ \\
\hline Assets & The total assets of firms. The unit is in a million RMB. \\
\hline Fixed Assets & The amount of fixed assets. The unit is in a million RMB. \\
\hline Liabilities & The total liabilities of firms. The unit is in a million RMB. \\
\hline Leverage & Book leverage, measured as the ratio of total liabilities over total assets. \\
\hline Sales & The total amount of sales. The unit is in a million RMB. \\
\hline Employee & The amount of employment. \\
\hline Fixed Assets Growth & The year-on-year growth of fixed assets. \\
\hline Employee Growth & The year-on-year growth of employees. \\
\hline Net Income Growth & The year-on-year growth of net incomes. \\
\hline ROA & It is calculated by dividing a firm's annual earnings by its total asset in the same year. \\
\hline TFP & A measure of firm-level efficiency, i.e., total factor productivity. \\
\hline Interest Rate & $\begin{array}{l}\text { The ratio of firm interest expense in CIC data divided by the total outstanding loans of the firm in year t- } 1 \text { in CBRC } \\
\text { data. The sample is restricted to firms in CIC data with bank loans outstanding }\end{array}$ \\
\hline $\mathrm{HHI}$ & $\begin{array}{l}\text { The Herfindahl-Hirschman Index of outstanding branch number before the shock for each city (i.e., higher HHI, less } \\
\text { competitive). }\end{array}$ \\
\hline Local GDP & It is the city level GDP. \\
\hline
\end{tabular}


Table A2: Provincial Distributions of J oint-equity Banks

This table shows the snapshot distribution of joint-equity banks in April 2009 (right before the deregulation). The table has 31 rows for 31 provinces respectively. For each province, there are four columns: (1) total number of branches of all 12 joint-equity banks, (2) total number of unique joint equity banks, (3) the total number of unique joint equity banks which have branches in its capital city and (4) the number of cities.

\begin{tabular}{lcccc}
\hline & $(1)$ & $(2)$ & $(3)$ & $(4)$ \\
\cline { 2 - 5 } Province & $\begin{array}{c}\text { No.J Jint-equity } \\
\text { Branches }\end{array}$ & $\begin{array}{c}\text { No. J oint-equity } \\
\text { Banks }\end{array}$ & $\begin{array}{c}\text { No. Joint-equity Banks } \\
\text { in Capital City }\end{array}$ & $\begin{array}{c}\text { No. } \\
\text { Cities }\end{array}$ \\
\hline Beijing & 332 & 10 & 10 & 1 \\
Tianjin & 128 & 10 & 10 & 1 \\
Hebei & 49 & 6 & 5 & 11 \\
Shanxi & 53 & 8 & 8 & 11 \\
Inner Mongolia & 14 & 4 & 4 & 9 \\
Liaoning & 206 & 9 & 7 & 14 \\
Jilin & 13 & 4 & 4 & 8 \\
Heilongjiang & 55 & 6 & 5 & 13 \\
Shanghai & 379 & 10 & 10 & 1 \\
Jiangsu & 311 & 11 & 11 & 13 \\
Zhejiang & 396 & 12 & 12 & 11 \\
Anhui & 50 & 6 & 6 & 18 \\
Fujian & 237 & 8 & 8 & 9 \\
Jiangxi & 29 & 4 & 4 & 11 \\
Shandong & 291 & 10 & 10 & 17 \\
Henan & 94 & 7 & 7 & 17 \\
Hubei & 127 & 8 & 8 & 14 \\
Hunan & 72 & 6 & 6 & 14 \\
Guangdong & 926 & 9 & 9 & 21 \\
Guangxi & 20 & 6 & 6 & 14 \\
Hainan & 14 & 2 & 2 & 3 \\
Chongqing & 119 & 8 & 8 & 1 \\
Sichuan & 117 & 11 & 11 & 21 \\
Guizhou & 0 & 0 & 0 & 9 \\
Yunnan & 104 & 9 & 9 & 16 \\
Xizang & 0 & 0 & 0 & 7 \\
Shaanxi & 89 & 8 & 8 & 10 \\
Gansu & 17 & 2 & 2 & 14 \\
Qinghai & 0 & 0 & 0 & 5 \\
Ningxia & 0 & 0 & 0 & 15 \\
Xinjiang & 26 & 4 & 4 & \\
\hline
\end{tabular}


Table A3: 4T Effect on Deregulated Bank-Cities and Regulated Bank-Cities

This table reports the comparisons of the growth rate of loans outstanding from November 2008 to March 2009 between deregulated bank-cities (i.e., treated groups) and regulated bank-cities (i.e., control groups). The growth rate of loans outstanding is calculated at the bank-city-month level. Thet-test was employed to show the significance of mean differences, and t-statistics are reported in parentheses.

\begin{tabular}{|c|c|c|c|c|c|c|}
\hline \multirow[b]{2}{*}{ From November 2008 to March 2009} & \multicolumn{2}{|c|}{ Before winsorization } & \multicolumn{2}{|c|}{ After winsorization } & \multicolumn{2}{|c|}{ After winsorization condition on Growth $>0$} \\
\hline & Mean & Std. Dev. & Mean & Std. Dev. & Mean & Std. Dev. \\
\hline Deregulated Joint Equity Bank-Cities (1) & $34.42 \%$ & $236.86 \%$ & $26.81 \%$ & $88.11 \%$ & $69.51 \%$ & $94.86 \%$ \\
\hline Deregulated Big Five Bank-Cities (2) & $32.67 \%$ & $89.96 \%$ & $30.06 \%$ & $61.61 \%$ & $40.54 \%$ & $62.84 \%$ \\
\hline Regulated Bank-Cities (3) & $32.75 \%$ & $121.47 \%$ & $27.65 \%$ & $89.37 \%$ & $52.36 \%$ & $103.97 \%$ \\
\hline Mean Difference (1)-(3) & $1.66 \%$ & & $-0.01 \%$ & & $17.15 \%$ & \\
\hline t-statistics (1)-(3) & $(0.06)$ & & $(-0.09)$ & & $(1.27)$ & \\
\hline Mean Difference (2)-(3) & $-0.08 \%$ & & $2.40 \%$ & & $-11.82 \%$ & \\
\hline$t$-statistics (2)-(3) & $(-0.01)$ & & $(0.34)$ & & $(-1.29)$ & \\
\hline
\end{tabular}




\section{Table A4: Incumbent banks vs. new entrant banks}

This table provides the differences in loan- and firm-level characteristics between incumbent banks and new entrant banks. The new entrant banks in a city are defined as those of which their earliest branches in this city are set up in less than 12 months before the loan issuing month. Loan Amount is loan balance in unit of Million RMB, Maturity is in unit of year, Rating Dummy measures the five-category loan classification where it takes the value of one if the internal rating equals one and zero if the internal rating is larger than 1, Guaranteed is a dummy indicating whether the loan is guaranteed by third parties, and Default is a dummy indicating whether the loan is repaid three months after due date. Assets measure the size of borrowers in a unit of 100 Million RMB while Leverage for financial conditions. We winsorize each of the above variables at the top and bottom $1 \%$ to reduce the effects of outliers. T-tests are also performed to show the statistical significance of the mean differences and tstatistics are reported in the last column. ${ }^{*},{ }^{* *}$, and ${ }^{* * *}$ indicate statistical significance at the $10 \%, 5 \%$, and $1 \%$ levels, respectively.

\begin{tabular}{|c|c|c|c|c|c|c|c|c|}
\hline & \multicolumn{3}{|c|}{ Incumbent Banks } & \multicolumn{3}{|c|}{ New Entrant Banks } & \multirow[b]{2}{*}{ Diff } & \multirow[b]{2}{*}{ t-statistics } \\
\hline & $\mathrm{N}$ & Mean & Media & $\mathrm{N}$ & Mean & Media & & \\
\hline & \multicolumn{8}{|c|}{ Overall Sample } \\
\hline 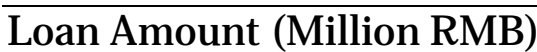 & $6,279,22$ & 15.031 & 4.000 & 52,09 & 22.06 & 9.798 & $7.029^{* * *}$ & 50.96 \\
\hline Maturity & $6,279,22$ & 0.997 & 0.500 & 52,09 & 0.950 & 0.583 & $-0.047^{* * *}$ & -5.65 \\
\hline Rating Dummy & $6,279,22$ & 0.979 & 1.000 & 52,09 & 0.995 & 1.000 & $0.016^{* * *}$ & 26.33 \\
\hline Guaranteed & $6,279,22$ & 0.206 & 0.000 & 52,09 & 0.294 & 0.000 & $0.088^{* * *}$ & 49.06 \\
\hline \multirow[t]{2}{*}{ Default } & $5,111,093$ & 0.011 & 0.000 & 41,780 & 0.006 & 0.000 & $-0.005^{* * *}$ & -9.31 \\
\hline & \multicolumn{8}{|c|}{ J oint-equity Bank Subsample } \\
\hline illion RMB) & $1,925,172$ & 14.43 & 3.213 & 51,375 & 22.220 & 10.000 & $7.785^{* * *}$ & 57.23 \\
\hline Maturity & $1,925,172$ & 0.733 & 0.500 & 51,375 & 0.930 & 0.583 & $0.197^{* * *}$ & 35.34 \\
\hline Rating Dummy & 1,925,172 & 0.993 & 1.000 & 51,375 & 0.996 & 1.000 & $0.003^{* * *}$ & 8.73 \\
\hline Guarantee Requirement & 1,925,172 & 0.233 & 0.000 & 51,375 & 0.295 & 0.000 & $0.062^{* * *}$ & 33.28 \\
\hline Default & $1,567,829$ & 0.006 & 0.000 & 41,175 & 0.006 & 0.000 & -0.000 & -0.51 \\
\hline
\end{tabular}




\section{Table A5: Effects of Deregulation on Big Five Banks}

This table presents the regression estimates of difference-in-differences analysis on the impact of deregulation shock in joint equity bank expansion on big five banks. The dependent variables are Log(1+Outstanding Loan) and Log(1+Number of Branches). The main independent variable is the interaction, After2009.4×Exposure, where After2009.4 equals one for observations after the policy shock in April 2009 and zero before and Exposure equals one for treated cities and zero for controlled cities. According to the policy, an eligible city j free of regulation on new-branch entry is the city where at least one of the joint-equity banks have outstanding branches in this city or in the capital city of the province that the city $\mathrm{j}$ is located in before the deregulation policy shock. Column (1) and (3) report the regression estimates for subsample during April 2008 to March 2010 (two-year event window) and column (2) and (4) report the regression estimates for subsample during April 2007 to March 2011 (four-year event window). Pretrend_1, Pretrend_2, and Pretrend_3 are the interactions between Exposure and the time dummies indicating the 1-month, 2-month, and 3-month before Apr 2009, respectively. Exposure, After2009.4, time dummies, and Log(City GDP) are included in all model specifications. Coefficients of these control variables are omitted for brevity. All variables are defined in Appendix Table A1. City-, Bank-, and Year-fixed effects are included across all models. Fixed effects estimates, including the constant, are omitted for brevity. The t-statistics in parentheses are based on the two-way cluster-robust standard errors (cluster by city and bank) across all these model specifications. *, **, and *** indicate statistical significance at the $10 \%, 5 \%$, and $1 \%$ levels, respectively.

\begin{tabular}{|c|c|c|c|c|}
\hline & \multicolumn{2}{|c|}{ Log (1 + No. Branches) } & \multicolumn{2}{|c|}{ Log $(1+$ Outstanding Loan $)$} \\
\hline & (1) & (2) & (3) & (4) \\
\hline & {$[200804,201003$} & ] [200704,201103] & {$[200804,201003]$} & {$[200704,201103]$} \\
\hline \multirow{2}{*}{ After2009.4×Exposure } & 0.016 & 0.021 & 0.002 & -0.055 \\
\hline & $(1.48)$ & (1.03) & $(0.04)$ & $(-0.77)$ \\
\hline \multirow[t]{2}{*}{ Pre-trend $d_{t-1}$} & & 0.005 & & 0.032 \\
\hline & & $(0.37)$ & & $(0.68)$ \\
\hline \multirow[t]{2}{*}{ Pre-trend $\mathrm{t}_{-2}$} & & 0.005 & & -0.038 \\
\hline & & $(0.33)$ & & $(-0.80)$ \\
\hline \multirow[t]{2}{*}{ Pre-trend $d_{t-3}$} & & 0.004 & & $-0.078^{*}$ \\
\hline & & $(0.30)$ & & $(-1.65)$ \\
\hline Controls & YES & YES & YES & YES \\
\hline City FE & YES & YES & YES & YES \\
\hline Bank FE & YES & YES & YES & YES \\
\hline Year FE & YES & YES & YES & YES \\
\hline Observations & 34,185 & 68,340 & 34,185 & 68,340 \\
\hline Adjusted R-squared & 0.862 & 0.861 & 0.851 & 0.853 \\
\hline
\end{tabular}


Table A6: Deregulation Effect on Local Deposits

This table presents the OLS regression estimates of difference-in-differences analysis of the banking deregulation effect on local deposits. The overall sample includes 1,740 cityyear observations with no null values, and the dependent variables are Log(1+ Local Deposit) and Local Deposits/Local GDP. The main independent variable is the interaction, After2009×Exposure, where After2009 equals one for observations after the year of 2009 and zero before and Exposure equals one for treated cities (at least one joint equity bank can open branches freely in that city after the deregulation, i.e., either the city or its capital city has outstandingjoint-equity branches prior to the bank expansion policy shock) and zero for controlled cities. We exclude the bank headquarter cities. The column (1) and (4) report the regression estimate only with year-fixed effect, the column (2) and (5) further include the Province-fixed effects, and the column (3) and (6) report the regression estimates with both City- and Year-fixed effects. Exposure, After2009.4, time dummies, and Log(City GDP) are included in all model specifications. Coefficients of these control variables are omitted for brevity. All other variables are defined in Appendix TableA1. Fixed effects estimates, including the constant, are omitted for brevity. Standard errors are clustered at the city level, and the robust t-statistics are reported in parentheses across all these model specifications. ${ }^{*},{ }^{* *}$, and ${ }^{* * *}$ indicate statistical significance at the $10 \%, 5 \%$, and $1 \%$ levels, respectively.

\begin{tabular}{|c|c|c|c|c|c|c|}
\hline & \multicolumn{6}{|c|}{ Local Deposits } \\
\hline & \multicolumn{3}{|c|}{ Log(1+ Local Deposits) } & \multicolumn{3}{|c|}{ Local Deposits/Local GDP } \\
\hline & (1) & $(2)$ & (3) & (4) & $(5)$ & (6) \\
\hline \multirow{2}{*}{ After2009×Exposure } & -0.089 & -0.087 & $-0.151^{*}$ & 0.012 & 0.017 & -0.121 \\
\hline & $(-1.20)$ & $(-1.16)$ & $(-1.89)$ & $(0.22)$ & $(0.32)$ & $(-1.48)$ \\
\hline Controls & YES & YES & YES & YES & YES & YES \\
\hline Province FE & NO & YES & NO & NO & YES & NO \\
\hline City FE & NO & NO & YES & NO & NO & YES \\
\hline Year FE & YES & YES & YES & YES & YES & YES \\
\hline Observations & 1,740 & 1,740 & 1,740 & 1,740 & 1,740 & 1,740 \\
\hline Adjusted R-squared & 0.852 & 0.900 & 0.979 & 0.150 & 0.391 & 0.829 \\
\hline
\end{tabular}


Table A7: Impacts of Deregulation on Interest Rates

This table presents the OLS regression estimates of difference-in-differences analysis of the banking deregulation effect on borrowing costs. The samplein Panel A restricts to CIC firms with outstanding loans in a given year and covers 124,830 firm-year observations. The dependent variable in Panel A is a proxy for interest rate, the ratio of interest payments over the amount of loans. Panel B reports the interaction analyses between deregulation effect and the firm's state ownership. The sample in Panel Cis from CSMAR loan database and includes 457 loan contracts with null values. The dependent variable in Panel $\mathrm{C}$ is the interest rate recorded in loan contracts. The main independent variable is the interaction, After2009×Exposure, where After2009 equals one for observations after 2009 and zero before and Exposure equals one for treated cities (at least one joint equity bank can open branches freely in that city after the deregulation, i.e., either the city or its capital city has outstandingjoint-equity branches prior to the bank expansion policy shock) and zero for controlled cities. Pre-trendt-1 and Pre-trendt-2 are for parallel pretrends, where Pre-trendt-1 equals year dummy for 2008 times Exposure and Pre-trendt-2 equals year dummy for 2007 times Exposure. Log(Assets), Leverage, Private, Exposure, After2009, and time dummies are included in all model specifications. Coefficients of these control variables are omitted for brevity. All other variables are defined in Appendix Table A1. Firm- and Year-fixed effects are included in Panel A and City- and Industryfixed effects are included in Panel B. Standard errors are clustered at the firm level, and the t-statistics are reported in parentheses across all these model specifications. *, **, and *** indicate statistical significance at the $10 \%, 5 \%$, and $1 \%$ levels, respectively.

\section{Panel A: CIC Sample}

\begin{tabular}{lcc}
\hline & \multicolumn{2}{c}{ Nominal Interest Rate $(\%)$} \\
\cline { 2 - 3 } & $(1)$ & $(2)$ \\
\hline After2009×Exposure & $-1.019^{* * *}$ & $-1.163^{* * *}$ \\
Pre-trend $_{\mathrm{t}-1}$ & $(-2.92)$ & $(-2.70)$ \\
& & -0.159 \\
Pre-trend & & $(-0.27)$ \\
& & -0.220 \\
Controls & & $(-0.33)$ \\
Firm FE & & YES \\
Year FE & YES & YES \\
Observations & YES & YES \\
Adjusted R-squared & YES & 108,580 \\
\hline
\end{tabular}

(to be continued) 
Table A7: Deregulation Effect on Interest Rate-continued Panel B: Interactions with Private Dummy for CIC Sample

\begin{tabular}{lcc}
\hline & \multicolumn{2}{c}{ Nominal Interest Rate (\%) } \\
\cline { 2 - 3 } PrivatexAfter2009×Exposure & $(1)$ & $(2)$ \\
After2009×Exposure & $-0.603^{* * *}$ & $-0.603^{* * *}$ \\
& $(-2.91)$ & $-0.92)$ \\
Pre-trend & -0.460 & $(-1.30)$ \\
& $(-1.19)$ & -0.167 \\
Pre-trend & & $(-0.28)$ \\
& & -0.221 \\
Controls & & $(-0.33)$ \\
Firm FE & & YES \\
Year FE & & YES \\
Observations & YES & YES \\
Adjusted R-squared & YES & 108,580 \\
& YES & 0.621 \\
\hline
\end{tabular}

Panel C: CSMAR Loan Sample

\begin{tabular}{lcccc}
\hline & \multicolumn{3}{c}{ Nominal Interest Rate (\%) } \\
\cline { 2 - 5 } & $(1)$ & $(2)$ & $(3)$ & $(4)$ \\
\hline After2009.4×Exposure & $-1.044^{* *}$ & $-1.069^{*}$ & $-8.005^{* * *}$ & $-6.083^{* * *}$ \\
& $(-2.05)$ & $(-1.89)$ & $(-7.87)$ & $(-2.86)$ \\
Controls & YES & YES & YES & YES \\
City FE & NO & NO & YES & YES \\
Industry FE & YES & YES & YES & YES \\
Year FE & YES & YES & YES & YES \\
Observations & 457 & 457 & 457 & 457 \\
Adjusted R-squared & 0.382 & 0.410 & 0.660 & 0.668 \\
\hline
\end{tabular}


Table A8: The Impacts of Deregulation on Big Five Banks' Credit Allocation This table reports the results of the DID regressions of the big five bank loan allocation between SOEs and private firms. The sample is restricted to big five banks. The dependent variables in Panel A are SOE loans outstanding and the percentage of loans to SOEs at the city-bank-month level. In Panel B, the dependent variables are the shares of outstanding loans to firms with higher TFP (i.e., High TFP Share) at the city-bank-month level. The main independent variable is the interaction, After2009.4×Exposure, where After2009.4 equals one for observations after the policy shock in April 2009 and zero before that. Exposure equals one in cities where some joint equity banks are allowed to freely expand after April 2009 and zero otherwise (i.e., unaffected bank-city). We also exclude the bank's headquarter cities. Pretrend_1, Pretrend_2, and Pretrend 3 are the interactions between Exposure and the time dummies indicating the 1-month, $\overline{2}$-month, and 3-month before April 2009, respectively. Exposure, After2009.4, and time dummies are included in all model specifications. Coefficients of these control variables are omitted for brevity. All variables are defined in Appendix Table A1. City-, Bank-, and Year-fixed effects are included across all models. The t-statistics in parentheses are based on the two-way cluster-robust standard errors (cluster by city and bank) across all these model specifications. ${ }^{*}, * *$, and ${ }^{* * *}$ indicate statistical significance at the $10 \%, 5 \%$, and $1 \%$ levels, respectively.

Panel A: Lending to SOEs

\begin{tabular}{|c|c|c|c|c|c|c|}
\hline & \multicolumn{6}{|c|}{ Dependent Variable: Loans to SOE } \\
\hline & \multicolumn{3}{|c|}{ Log(Outstanding Loans) } & \multicolumn{3}{|c|}{ SOE-Share } \\
\hline & (1) & $(2)$ & (3) & (4) & (5) & (6) \\
\hline & 1-Year & 2-Year & All & 1-Year & 2-Year & All \\
\hline \multirow[t]{2}{*}{ After2009.4×Exposure } & 0.068 & 0.024 & 0.224 & 0.005 & 0.021 & 0.027 \\
\hline & $(0.45)$ & $(0.12)$ & $(1.21)$ & $(0.27)$ & $(0.88)$ & (1.17) \\
\hline \multirow{2}{*}{ Pre-trendt-1 } & & 0.062 & 0.085 & & 0.009 & 0.014 \\
\hline & & $(0.33)$ & $(0.44)$ & & $(0.40)$ & $(0.60)$ \\
\hline \multirow[t]{2}{*}{ Pre-trendt-2 } & & 0.204 & 0.220 & & 0.014 & 0.018 \\
\hline & & $(1.41)$ & (1.44) & & $(0.62)$ & $(0.76)$ \\
\hline \multirow[t]{2}{*}{ Pre-trendt-3 } & & 0.120 & 0.129 & & 0.014 & 0.018 \\
\hline & & $(0.88)$ & $(0.89)$ & & $(0.76)$ & $(0.92)$ \\
\hline Controls & Yes & Yes & Yes & Yes & Yes & Yes \\
\hline City FE & Yes & Yes & Yes & Yes & Yes & Yes \\
\hline Bank FE & Yes & Yes & Yes & Yes & Yes & Yes \\
\hline Year FE & Yes & Yes & Yes & Yes & Yes & Yes \\
\hline Observations & 32,016 & 65,623 & 110,098 & 32,016 & 65,623 & 110,098 \\
\hline Adjusted R-squared & 0.686 & 0.613 & 0.629 & 0.520 & 0.491 & 0.485 \\
\hline
\end{tabular}

(to be continued) 
Table A8: The Impacts of Deregulation on Big Five Banks' Credit Allocation-continued

Panel B: Lending to Efficient Firms

\begin{tabular}{|c|c|c|c|c|c|c|}
\hline & \multicolumn{6}{|c|}{ Dependent Variable: High TFP Share } \\
\hline & \multicolumn{3}{|c|}{ For SOEs } & \multicolumn{3}{|c|}{ For Private Firms } \\
\hline & (1) & (2) & (3) & (4) & (5) & (6) \\
\hline & 1-Year & 2-Year & All & 1-Year & 2-Year & All \\
\hline \multirow[t]{2}{*}{ After2009.4×Exposure } & -0.024 & -0.024 & -0.015 & -0.016 & -0.010 & -0.019 \\
\hline & $(-1.09)$ & $(-0.78)$ & $(-0.44)$ & $(-0.71)$ & $(-0.32)$ & $(-0.55)$ \\
\hline \multirow[t]{2}{*}{ Pre-trendt-1 } & & -0.011 & -0.010 & & -0.009 & -0.004 \\
\hline & & $(-0.44)$ & $(-0.38)$ & & $(-0.37)$ & $(-0.14)$ \\
\hline \multirow[t]{2}{*}{ Pre-trendt-2 } & & -0.018 & -0.015 & & -0.006 & -0.002 \\
\hline & & $(-0.85)$ & $(-0.67)$ & & $(-0.25)$ & $(-0.07)$ \\
\hline \multirow[t]{2}{*}{ Pre-trendt-3 } & & -0.014 & -0.011 & & -0.002 & 0.003 \\
\hline & & $(-0.74)$ & $(-0.54)$ & & $(-0.08)$ & $(0.12)$ \\
\hline Controls & Yes & Yes & Yes & Yes & Yes & Yes \\
\hline City FE & Yes & Yes & Yes & Yes & Yes & Yes \\
\hline Bank FE & Yes & Yes & Yes & Yes & Yes & Yes \\
\hline Year FE & Yes & Yes & Yes & Yes & Yes & Yes \\
\hline Observations & 24,893 & 51,147 & 86,396 & 31,168 & 63,785 & 107,421 \\
\hline Adjusted R-squared & 0.529 & 0.501 & 0.483 & 0.356 & 0.330 & 0.313 \\
\hline
\end{tabular}


Table A9: Descriptive Statistics of Borrower Characteristics

This table reports the descriptive statistics of borrower characteristics. Panel A reports the mean difference tests on operating efficiency variables between SOE borrowers and private borrowers, i.e., ATR (Asset Turnover Ratio) and TFP. For SOE subsample, Panel B reports the mean difference tests on the proportion of borrowers at higher hierarchy and size between the lower-TFP group and the higher-TFP group. Borrowers in Lower TFP group are those of which TFP estimated is lower than the median value. Higher Hierarchy takes the value of one if the borrower's hierarchy is at the city level or above. T-tests are also performed to show the statistical significance of the mean differences and tstatistics are reported in parentheses. *, **, and *** indicate statistical significance at the $10 \%, 5 \%$, and $1 \%$ levels, respectively.

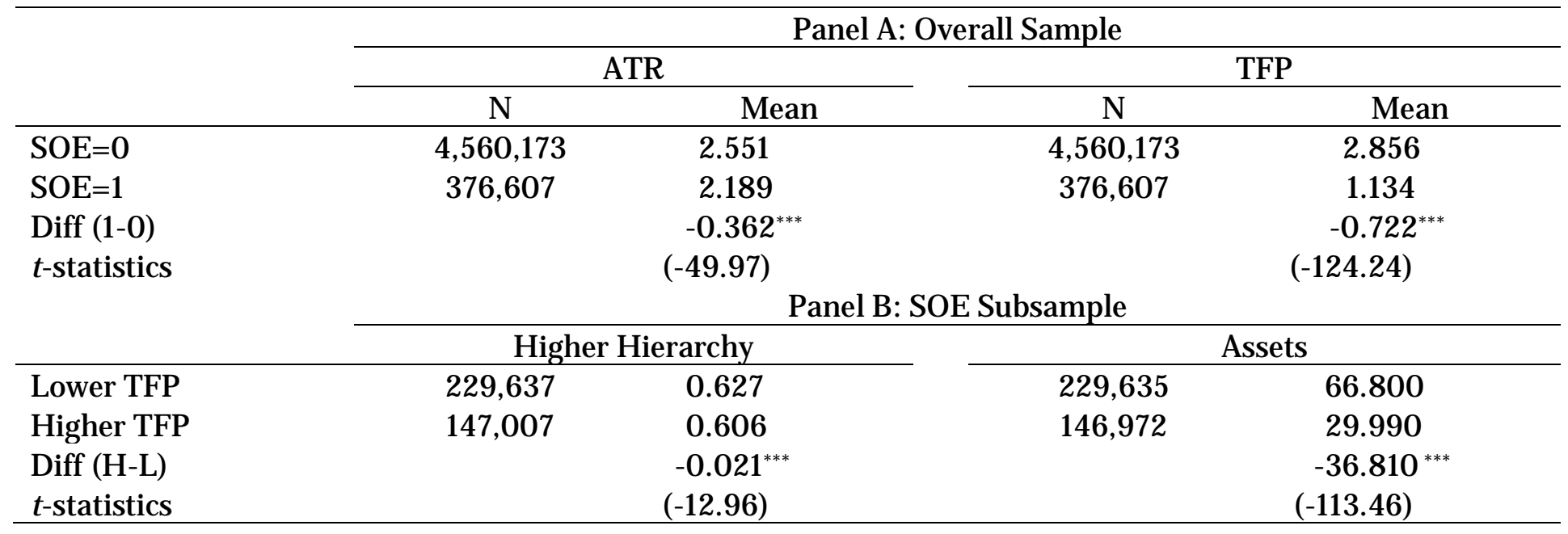




\section{Table A10: Pre-trend Analyses}

This table reports the difference-in-differences regression estimates of the bank expansion effect on how banks target borrowers. The dependent variables are the percentage of loans to SOEs and the logarithm of SOE loans outstanding at the city-bankmonth level. The main independent variable is the interaction, $M$ jxExposure, where $M$ j equals one for observations in month $j$ ( $j$ is from April 2008 to March 2010) and zero otherwise. Exposure equals one for the joint equity bank $\mathrm{k}$ in city $\mathrm{j}$ if it has outstanding branches in city j or the capital city of the province that the city j is located in before April 2009 (i.e., deregulated bank-city) and equals zero for joint equity banks in still regulated cities and big five banks in cities where no joint equity banks are allowed to freely expand after April 2009 (i.e., unaffected bank-city). We also exclude the bank's headquarter cities. Time dummies are included in all model specifications. Coefficients of these control variables are omitted for brevity. All variables are defined in Appendix Table A1. City-, Bank-, and Year-fixed effects are included across all models. The t-statistics in parentheses are based on the two-way cluster-robust standard errors (cluster by city and bank) across all these model specifications. ${ }^{*},{ }^{* *}$, and ${ }^{* * *}$ indicate statistical significance at the $10 \%, 5 \%$, and $1 \%$ levels, respectively.

\begin{tabular}{|c|c|c|}
\hline & $\begin{array}{c}\text { Dependent Variable: } \\
\text { Percentage of Loans to SOEs }\end{array}$ & $\begin{array}{l}\text { Dependent Variable: } \\
\text { Log(SOE Loans) }\end{array}$ \\
\hline & [200704, 201103] & {$[200704,201103]$} \\
\hline \multirow[t]{2}{*}{ Exposure } & 0.004 & -0.034 \\
\hline & $(0.23)$ & $(-0.91)$ \\
\hline \multirow[t]{2}{*}{ After2009.4 } & 0.003 & -0.009 \\
\hline & $(0.85)$ & $(-0.52)$ \\
\hline \multirow[t]{2}{*}{ Exposure $\times$ M2008.04 } & 0.012 & -0.027 \\
\hline & $(0.34)$ & $(-0.13)$ \\
\hline \multirow[t]{2}{*}{ Exposure $\times$ M2008.05 } & 0.004 & -0.068 \\
\hline & $(0.12)$ & $(-0.31)$ \\
\hline \multirow[t]{2}{*}{ Exposure $\times$ M2008.06 } & 0.007 & -0.080 \\
\hline & $(0.19)$ & $(-0.36)$ \\
\hline \multirow[t]{2}{*}{ Exposure $\times$ M2008.07 } & -0.016 & -0.163 \\
\hline & $(-0.46)$ & $(-0.75)$ \\
\hline \multirow[t]{2}{*}{ Exposure $\times M 2008.0$} & -0.018 & -0.087 \\
\hline & $(-0.53)$ & $(-0.41)$ \\
\hline \multirow[t]{2}{*}{ Exposure $\times$ M2008.09 } & 0.005 & -0.027 \\
\hline & $(0.16)$ & $(-0.13)$ \\
\hline \multirow[t]{2}{*}{ Exposure×M2008.10 } & 0.007 & -0.078 \\
\hline & $(0.22)$ & $(-0.40)$ \\
\hline \multirow[t]{2}{*}{ Exposure×M2008.11 } & 0.010 & 0.035 \\
\hline & $(0.33)$ & $(0.19)$ \\
\hline
\end{tabular}




\begin{tabular}{|c|c|c|}
\hline \multirow[t]{2}{*}{ Exposure×M2008.12 } & 0.024 & 0.125 \\
\hline & $(0.89)$ & $(0.73)$ \\
\hline \multirow[t]{2}{*}{ Exposure×M2009.01 } & 0.017 & 0.048 \\
\hline & $(0.74)$ & $(0.33)$ \\
\hline \multirow[t]{2}{*}{ Exposure $\times$ M2009.02 } & 0.016 & 0.058 \\
\hline & $(0.77)$ & $(0.42)$ \\
\hline \multirow[t]{2}{*}{ Exposure $\times$ M2009.03 } & 0.025 & 0.118 \\
\hline & $(1.28)$ & $(0.89)$ \\
\hline \multirow[t]{2}{*}{ Exposure $\times$ M2009.04 } & 0.030 & $0.302^{*}$ \\
\hline & $(1.09)$ & $(1.80)$ \\
\hline \multirow[t]{2}{*}{ Exposure $\times$ M2009.05 } & $0.061^{* *}$ & $0.486^{* * * *}$ \\
\hline & $(2.39)$ & $(2.74)$ \\
\hline \multirow[t]{2}{*}{ Exposure $\times$ M2009.06 } & $0.071^{* *}$ & $0.652^{* * *}$ \\
\hline & $(2.39)$ & $(3.34)$ \\
\hline \multirow[t]{2}{*}{ Exposure $\times$ M2009.07 } & $0.064^{*}$ & $0.608^{* * *}$ \\
\hline & $(1.96)$ & $(2.90)$ \\
\hline \multirow[t]{2}{*}{ Exposure×M2009.08 } & $0.074^{* *}$ & $0.689^{* * *}$ \\
\hline & $(2.22)$ & $(3.07)$ \\
\hline \multirow[t]{2}{*}{ Exposure $\times$ M2009.09 } & $0.066^{* *}$ & $0.700^{* * *}$ \\
\hline & $(1.99)$ & $(3.10)$ \\
\hline \multirow[t]{2}{*}{ Exposure×M2009.10 } & $0.073^{* *}$ & $0.719^{* * *}$ \\
\hline & $(2.12)$ & $(3.14)$ \\
\hline \multirow{2}{*}{ Exposure×M2009.11 } & $0.090^{* *}$ & $0.830^{* * *}$ \\
\hline & $(2.50)$ & $(3.52)$ \\
\hline \multirow[t]{2}{*}{ Exposure×M2009.12 } & $0.082^{* *}$ & $0.753^{* * *}$ \\
\hline & $(2.30)$ & $(3.24)$ \\
\hline \multirow[t]{2}{*}{ Exposure×M2010.01 } & $0.080^{* *}$ & $0.739^{* * *}$ \\
\hline & $(2.26)$ & $(3.27)$ \\
\hline \multirow[t]{2}{*}{ Exposure $\times$ M2010.02 } & $0.083^{* *}$ & $0.839^{* * *}$ \\
\hline & $(2.31)$ & $(3.57)$ \\
\hline \multirow[t]{2}{*}{ Exposure $\times M 2010.03$} & $0.066^{*}$ & $0.764^{* * *}$ \\
\hline & $(1.83)$ & $(3.23)$ \\
\hline Controls & Yes & Yes \\
\hline City FE & Yes & Yes \\
\hline Bank FE & Yes & Yes \\
\hline Year FE & Yes & Yes \\
\hline Observations & 55,155 & 55,166 \\
\hline Adjusted R-squared & 0.406 & 0.665 \\
\hline
\end{tabular}

